\title{
0
}

$\mathrm{SH} 441$

P96

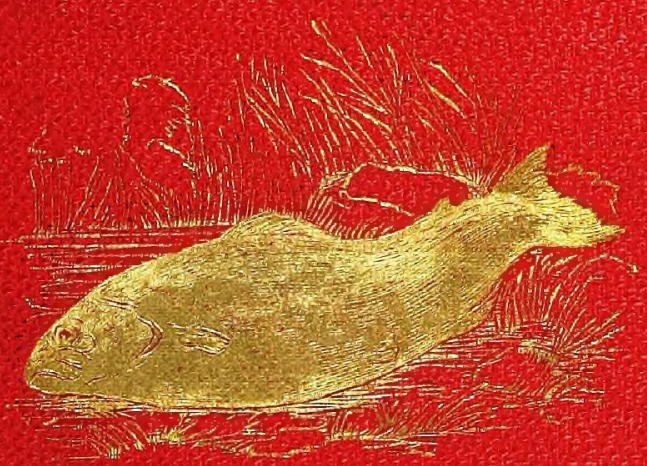




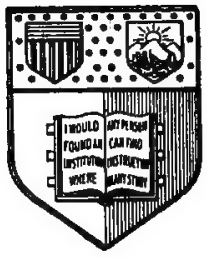

\section{Bew 韭art}

State College of Agriculture

\section{At Cormell Anibersity}

Jithaca, 2. 2 .

\section{Zubrary}




\section{Cornetl University Library \\ SH 441.P96}

Fish:their habits and haunts and the met

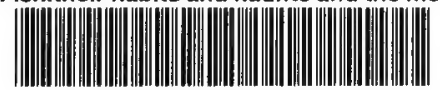

31924003263161 


\section{Cornell University Library}

The original of this book is in the Cornell University Library.

There are no known copyright restrictions in the United States on the use of the text.

http://www.archive.org/details/cu31924003263161 



\section{APPLETON \& LITCHFIELD,}

SUCCESSORS TO PROUTY \&O APPLETON,

ImPORTERS AND RETAILERS OF

\section{FINE CUTLERY AND FISHING TACKLE}

RODS, REELS, and LINES of every description.

ARTIFICIAL FLIES of all kinds.

LEONARD'S and NICHOLS' SPLIT BAMBOOS.

ENGLISH POCKET and TABLE CUTLERY of the Best Makes.

SPORTSMEN'S and HUNTING KNIVES.

FINE RAZORS, warranted to give satisfaction.

SHAVING ARTICLES.

HAMMOCKS in great variety.

CAMP LANTERNS and AXES.

FISHING SUITS and SHOES.

\section{APPLETON \& LITCHFIELD,}

304 WASHINGTON StREET,

(2d door North of the Old South)

BOSTON, MASS. 


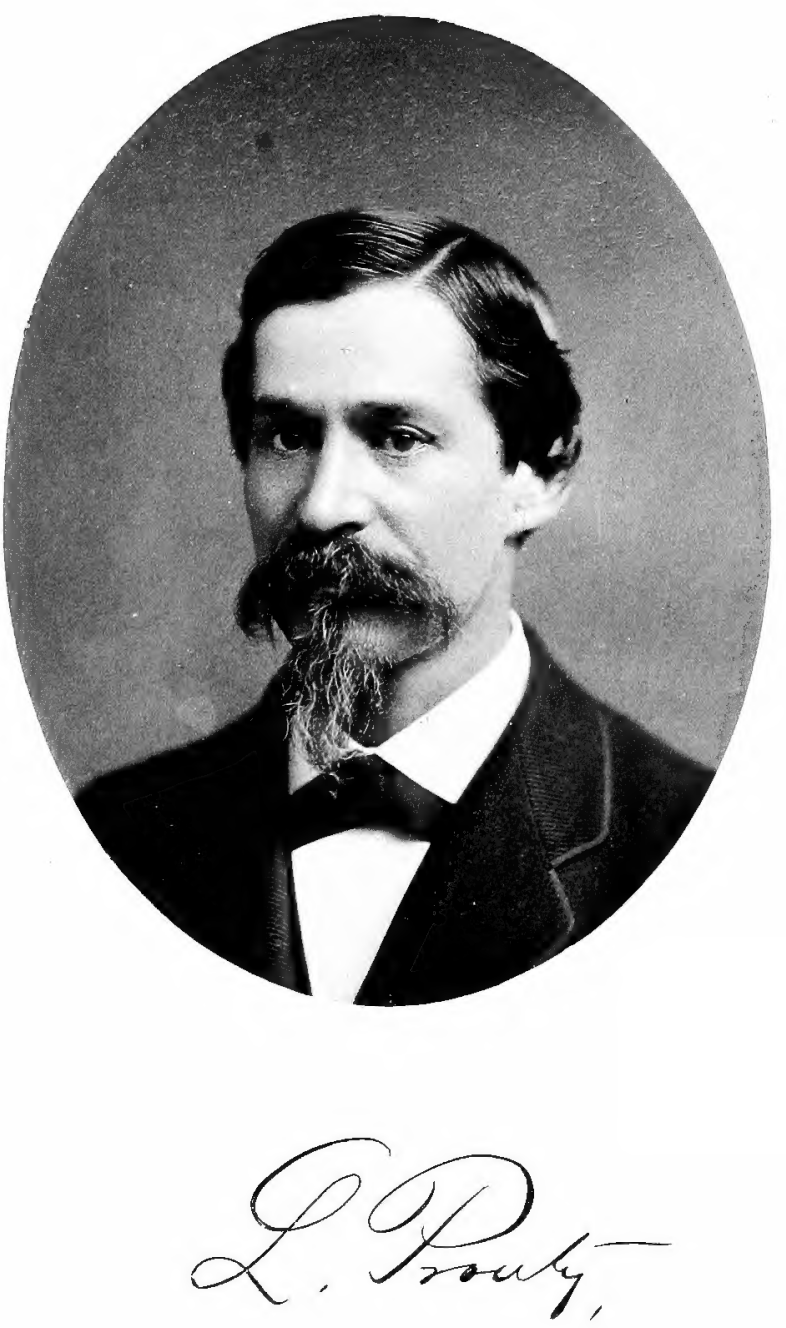




\section{F I S H :}

\section{THEIR HABITS AND HAUNTS}

AND THE

Ittetyods of Catching Them, TOGETHER WITH

FISHING AS A RECREATION.

BY

LORENZO PRÓUTY.

"In such green palaces the first kings reigned, Slept in their shades, and angels entertained; With such old counsellors they did advise, And by frequenting sacred groves grew wise."

BOSTON :

CUPPLES, UPHAM AND COMPANY, Dib Crarner Bookstare.

I883.

5 
Copyright, by

Cuprles, Upham and Company, 1883.

ELECTROTYPED.

BOSTON STEREOTYPE FOUNDRY, 4 TEARL STREET. 
To

Che fatury Jriends of the Author

WHO IN PAST YEARS

HAVE ENCAMPED WITH HIM IN FOREST AND BY STREAM, AND WHO DOUBTLESS IN READING THIS LITTLE VOLUME WILL RECALL HIS PRESENCE

WITH PLEASANT MEMORIES;

AND

TO THOSE READERS WHO NOT HAVING KNOWN HIM

WILL FROM THESE PAGES

MAKE SOME ACQUAINTANCE WITH HIS

LIFE AND CHARACTER. 



\section{CONTENTS.}

Page

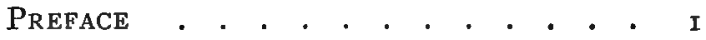

General Remarks . . . . . . . . . 9

Fresh-Water Fish . . . . . . . . . I6

The Angler's Apparatus . . . . . 27

Rods and Lines . . . . . . . . . 29

Floats and Landing-Nets . . . . . $3^{6}$

Fly-Fishing . . . . . . . . . . $3^{8}$

Dabbing . . . . . . . . . . 40

Minnow-Spinning . . . . . . . . $4 \mathrm{I}$

Bоtтом-Fishing . . . . . . . . . . 44

Baits FOR TROUt . . . . . . . . . 46

The Salmon . . . . . . . . . . 48

The Blue Fish . . . . . . . . . $55^{2}$

The Black Fish . . . . . . 55

The Mackerel . . . . . . . $5^{8}$

The Scaupaug-Scup . . . . .

The Common Shad . . . . . . 60 
The PerCh . . . . . . . . . . 60 The Smelt . . . . . . . . . 64 TRIP to KeMPT, N. S., IN I879. . . . 65 Trip to Nova Scotia in i 88 I . . . 7 I A Day on Grand Lake . . . . . . 82 Two Days at Skiff Lake . . . . 85 Trip to Schoodie LaKe in r882 . • 86 TRAPS . . . . . . . . . . . . IOI In Memoriam . . . . . . . . . . 105 


\section{PREFACE.}

THE material of which this book is largely composed is from notes and manuscripts which Mr. Prouty had been preparing during the last few years of his life, suggested by his experience in camp-life and active business pursuits, with the intention of presenting them to the public when the proper occasion should come. Hence, in the compilation, the book is not expected to be so complete as it would have been could he have lived long enough to have had the arrangement himself, and have added more of his own practical experience and suggestions.

Mr. Prouty was born in Boston in 1839, removed to Dorchester in $184 \mathrm{I}$, and, passing through the Grammar School, graduated at Chauncy Hall School, in Boston. 
From early boyhood he manifested particular interest in fishing and angling, and every opportunity was seized to indulge in this favorite pastime. In 1855 he entered the hardware store of Martin L. Bradford, and naturally drifted into the department of fishing-tackle, to which he gave his closest attention, to make himself familiar with all its details. His great love of the sport, his experience in the forest and stream, and his practical common sense, enabled him to master this branch of their business, and he aided largely its rapid growth and success during the last few years of his life. In fact, so well had he become known by the lovers of this delightful art, that he was made an offcer of the Anglers' Association of Boston, and was often quoted as an authority upon angling throughout the land.

Of a modest and retiring nature, upright in all his dealings with his fellow-men, and of the keenest sensibilities, he made friends 
daily, and never forfeited the friendship of any.

When, after the confinement and arduous duties of his business life, he left all behind for the pleasure of the camp, to indulge in its sport for rest and recreation, and to enjoy the grandeur and teaching of nature, as only those who are lovers of this noble and lifegiving art can truly enjoy them, away from. all the busy hum of the city, in the solitude of the wilderness, then did he fully realize that communion with his Father and God, whom he loved with the simplicity of a child.

To the friends who have shared with him his camp-life, it would be a pleasure to recall the many conversations they have had with him in those still evening hours, whilst the same beautiful moon looked down so brightly on them and on their loved ones at home, and naught disturbed the silence but the hoot of the solitary owl.

His sudden death, at the close of the de- 
parted year, just when the future was opening to him a career of usefulness and honor, came like the "pall of night" to his large circle of frienas, as they realized that never more would his familiar face and welcome smile greet them.

How better could this brief memorial sketch be closed than by giving this tribute, sent to his beloved wife, from one of his guides in the forest home, which is but the echo of all who had the pleasure of his acquaintance :-

Kempt, Queens County, N. S., April I, 1883.

My Dear Mrs. Prouty, - Your letter and picture came safely to hand. We all think that the picture is perfect, and so much like him that we think he must speak to us; we are very much pleased to have it, and will keep it as long as we live, which will help to keep him fresh in our minds, though it is with sad hearts that we look upon it, know- 
ing that we can never see him more. We were of the same age, and in one respect alike : we loved the forest and stream, and he said to me, "I plan to come down here so long as I live, and always want you to go with me." He had planned for you to come with him next fall, and had our camp-ground selected, and my wife and daughter thought so much of having you come; but we will look in vain. I have been with many parties, and will go with many more, and where we used to go; and how many things I will see to remind me of him, and cause the tears to fill my eyes, which I will not have strength to keep down, - such as the pools where we have fished, the spots where we have lain, and the trees he has felled with his own hands. All these things will bring to mind the pleasant hours that we have spent together, which never can be recalled.

Mr. Prouty endeared himself to all who knew him down here, and many of my friends 
speak sadly of his death. As for myself, it has caused a sadness which will last through life, and which words fail to describe, for he to me was a true friend and a brother, and I think how little I have done for him to what he has done for me; he never knew how much I thought of him for his acts of kindness to me and to my family; look where. I will about my home, I can see something to remind me of him.

Please excuse me for writing so much, and be sure he is mourned in more homes than one. My wife, daughter, and myself deeply sympathize with you and your dear daughter, whom to us he so often spoke of. May God comfort and protect you both, and permit you to meet him in the world to come, where parting will not be known, and tears will never flow.

Yours in love,

David Freeman. 
FISH: THEIR HABITS AND HAUNTS. 



\section{FISH :}

\section{THEIR HABITS AND HAUNTS.}

THE Art of Angling is a very ancient one.

It is difficult to say when it did not exist. Representations of fish and of fishing have been found upon some of the oldest tombs and most venerable remains extant.

In every community of savage life are found instruments of angling, - rude enough, but sufficiently effective for the wants of those who employ them, - showing the various inventions for fishing to have been primitive and universal.

One of the first treatises on angling in the English language is that of Dame Julianna Bernes, published in 1496. The next is by the well-known Isaac Walton, in 1653 ; and since then the number of works of this 
character has constantly increased, - indeed, hardly any other subject has had so much written about it. This is not strange, when we consider that more than three-fourths of the earth's surface is covered with water, and teems with life in various forms. (

Naturalists of the present day know of upwards of thirteen thousand varieties of fish, of which perhaps one-tenth belong to freshwater.

The importance of the fisheries on our own. coasts can hardly be exaggerated, whether we consider the amount of wholesome food which they yield, the pecuniary value of their product, the number of persons employed, the stimulus furnished to ship and boat-building, and, not least of all, their ser-• vice as a school for seamen, from which the merchant marine, as well as the navy of the country, derives its most important recruits. The rapid growth of the country, the construction of railroads, and the use of 
FISH: THEIR HABITS AND HAUNTS. I I

ice for packing, have furnished facilities for sending fish in good condition to all markets; and the demand for them has increased in proportion. The discovery that fish could be made to yield a valuable oil by boiling has contributed an additional means of consumption, and more recently the packing of fish in tins prepared to keep them fresh for any length of time has given employment to both capital and men. But it is with the fish which we take for our sport that we are here concerned. In the sea about our own coast we find the cod, haddock, mackerel, tautog, perch, smelt, striped bass, and bluefish.

The cod and haddock are taken in water from fifty to one hundred feet deep, with a strong line and sinkers heavy enough to keep it down, and usually with two hooks baited with clams. They swim near the bottom, and when they are biting freely afford considerable sport. 
I2 FISH : THEIR HABITS AND HAUNTS.

The most beautiful of our salt-water fish, the mackerel, appears on our coast during the month of May. Swimming near the surface, it is taken with a small hook with a bright piece of metal attached to make it sink rapidly and at the same time to attract the fish. Each person uses two of these hooks and lines. In order to lure the fish about the boat, "wash-bait" — that is, fish ground up fine and mixed with water is thrown over, a little at a time. It is the superior attraction of the metal bait which captures them. When fishing from the deck of a mackerel schooner, with all hands engaged, the scene is exciting in the extreme. Each man has a tub to throw his catch in, and the constant flopping of the fish reminds one of a drum-corps in active operation.

The smelt, although small, is a choice fish, and is readily taken from June till winter with hook and line and stiff rod. In 
FISH : THEIR HABITS AND HAUNTS.

the winter it is taken through the ice in the river mouths.

The tautog and perch are found near rocks, upon the muscles, attached to which they are accustomed to feed. They may be caught with hand lines from a boat anchored near the 'spot, or with a long rod and line from the shore. The tautog is a strong fish; he takes his bait boldly, and starts for the bottom with it, and if of good size he gives some excitement and pleasure in the taking. Perch are usually plenty, and are easily taken. As they have small mouths, small hooks should be used.

Bluefish, formerly very plenty during the summer months, are not at present often found this side of Cape Cod; but the pleasure of taking them will well repay a journey to the south side, or even to Nantucket and Martha's Vineyard. The best method of taking them is from a sail-boat. Two or even four can fish at once. Fifty yards 
I4 FISH: THEIR HABITS AND IIAUNTS.

of strong line should be used, and a hook with metal run on it to load it, and covered with an inverted eel-skin for a bait. The lines are trailed behind the boat when four are fishing at once, and an outrigging of wood is fastened at the stem, so as to keep them from running too close together. With the boat under full sail, all lines out, and each one expectant, the excitement is intense; when the fish are reached, and one feels a twitch on his line, he begins to haul in as fast as possible, and if not quick enough his fish springs ahead and drops the hook. Often there will be a fish on each line at once, and then such fun, all pulling together! The fish weigh from four to ten pounds each. The skipper endeavors to keep the boat in the vicinity of the school, and tacks about to run through it, but often loses sight of it, for when feeding with the current the fish move rapidly. 
When plenty, from fifty to one hundred fish are often taken a day, and it is thoroughly tiresome work.

The striped bass is the king of salt-water fish, and in the opinion of many gives as much sport as the salmon. Twenty years ago many were taken from the bridges in Boston harbor, but with the growth of the city the waters have become less pure, and bass are now scarce there.

At many points on Cape Cod and south of it there is still opportunity for this sport. The method of fishing is to use a short, stiff rod of eight feet in length, a reel with six hundred feet of line, and a hook baited with a piece of eel. From some rocky point well out in the sea the bait is cast as far as possible. The fish are moving about looking for food, and if hungry take in the bait. When one is hooked it is quite a trial of skill and patience to capture him, as, full of strength and courage, he will 
I6 FISH: THEIR HABITS AND HAUNTS.

try every possible means to break away. But when landed, if of good size, say from twenty-five to fifty pounds, he will amply repay all trials and disappointments. Many of the islands south of Cape Cod are owned by clubs which have fitted up houses and employ men to "chum" or feed the fish so as to keep them about the rocks, and thus the owners are quite sure of sport whenever the weather is favorable.

\section{Fresh-Water Fish.}

In the fresh-water ponds and rivers are found the salmon, trout, pickerel, black bass, and perch.

The pickerel lives in the warmer waters and more sluggish streams; it spawns in the spring, and is in good condition most of the year. Very good sport may be had in trolling for it with the spoon baits, or with small fish. In the winter, it is captured by setting lines in holes cut through the ice. 
The black bass was brought to Massachusetts by Mr. Tisdale, of Wareham, about thirty years ago, from New York, and has been placed in many ponds, until now it is so plenty as to take the most prominent place among our fresh-water fish. Larger than the perch, and full of pluck, it affords much pleasure in the capture. The ponds in Plymouth are well stocked with bass, and many Boston people go there to fish.

I think few are aware what a pleasant town Plymouth is, and what opportunities it. offers for fishing and other sports. Although so near to Boston, its woods and lakes are as wild as when the Pilgrims landed.

The trout is the most beautiful of all fish, and has afforded recreation for thousands of years to lovers of nature throughout the Temperate Zone. The most plenty of all the game fish, it may be angled for with the commonest tackle, as a willow stick cut by the side of the stream, or with 
I8 FISH: THEIR HABITS AND HAUNTS.

very elaborate apparatus, and in either case it gives to the enthusiastic fisherman the keenest delight.

The old and young, the learned and ignorant, the poor and rich, all classes, ages and conditions, have enjoyed angling for trout. Once, nearly every stream in the Middle, Northern, and Eastern States teemed with both trout and salmon. The salmon has been driven away, and, had not anglers interfered to save the trout, they would now be known only from books and from the stories of the oldest inhabitants.

For bait-fishing, the convenient tackle is a light rod of ten or twelve feet in length, with reel and line, and small hooks, with well-scoured worms for bait. The stream should be approached with the greatest caution, as this fish is very wary, and the line should be dropped lightly into the water, and in an instant the fisherman may be rewarded by a sudden pull and the landing of 
a fine trout. But to enjoy trout-fishing at its best necessitates longer journeys and camping out, requires more thought and preparation. Where to go, how long to stay, what to carry, and what will be the expense, are the questions that arise.

Most of the camping trips from this lo. cality are made either to Maine, to New York, or to the Provinces. Maine offers the best and handiest grounds. Trips may be made to the Rangely Lakes, Moosehead Lake, Grand Lake Stream, or the Dead River country, with good success, either for fishıng or hunting; and it is from such trips, when we give nature a chance to deal with us in her own way, that we experience wonderful benefits to our mental and physical strength.

In the constant struggle of business requirements the human system can hardly hold its own. It needs a rest at least once a year; and not a rest only, but a change 
20 FISH: THEIR HABITS AND HAUNTS.

of occupation, thought, and mode of life; and nothing affords this so well as a trip to the woods When exhausted physically, one may not be equal to a hunting trip; but he can endure the light task of fishing, while to succeed in this requires sufficient thought to keep his mind from drifting away to home cares, and the exercise in the open air provokes an appetite that is astonishing. It has been said that man degenerates without frequent communion with nature. It certainly is true that this communion increases his reverence for and his appreciation of the beautiful in nature.

To one making his first trip how delightfully new and strange all seems! After completing your journey to the stream, or point of departure, you are probably met at the landing by your guide, who, after shaking. - hands and answering a few questions about the possible sport and the parties already in the woods, begins to arrange the things, 
or "traps," as they are called, in the canoe. "Will that little thing," you wonder, "made of birch bark and weighing not over fifty pounds, carry us safely?" But your respect for it begins at once; and as you spend day after day in the bow, permitted to handle the light paddle, and see how skilfully the guide runs the rapids, avoiding the rocks that seem ready to destroy the canoe, you become attached to the frail craft with an affection which you cannot forget when the trip is ended.

Then the changing views of the winding river as you move rapidly along causes an ever new delight. At noon you step out on some smooth beach well shaded by tall trees, to prepare the noon meal, and how you watch every motion of the guide as he gathers the few sticks needed to start a fire! And when at length you are seated on some smooth stone, holding your tin plate in your lap, and with your tin of tea close 
at hand, you wonder what the folks at home would think.

After a rest you start on again with renewed interest, the guide meanwhile, if talkative, telling about his experiences in the woods. And toward evening, when a good spot offers, he suggests that you had better encamp. Now there is still more novelty. After getting the things out of the birch and lifting it carefully from the water, the guide starts back with his axe and soon returns with long sticks to build the camp.

You look on eager to help, but ignorant what to do. He selects a good, smooth spot, sets up two saplings with crotched ends, about eight feet apart, and lays another across about six feet from the ground. Then several are laid with one end on the cross-piece, the other on the ground, making a skeleton shed. He now peels some birch bark in large pieces, and proceeds to shingle the top by lapping the pieces over each 
other, all being held in place by more poles. The ends are closed in by stakes driven down and more bark. You now see that you can be useful in getting fir boughs to make a bed, and plenty of them. When done, you look with much satisfaction on your first house. If not expensive, it promises to be very comfortable, and scarcely more than an hour has been occupied in the building of it.

The guide now starts to fell a tree for firewood, and in a few minutes you hear the crash, and think "To-morrow I must try the axe." Soon he appears with the pieces of wood, and you watch the operation of building a fire. First two short pieces are laid down for andirons; then a heavy long piece across for a backlog; then small pieces for the front, and, when ready, he lights up, and soon all is in a ruddy blaze. Now begin preparations for supper. Here you can help, and the meal is quickly prepared. After 
24 FISH : THEIR HABITS AND HAUNTS.

supper you talk a little, smoke if you wish, and are soon all ready to roll up in your blanket, and find your boughs a right comfortable couch. While lost in sleep, your mind miles away, you suddenly start up. A most terrific scream greets your ears at no great distance, and another, answering, from the opposite side. Your hair fairly stands on end. "What 's that?" you ask. "Oh, nothing but the owls," answers the guide; and he turns over and is asleep at once. You lie some time before you are lost again.

Morning comes. You are awake early, and ready to jump up. The guide takes it rather more easily, but soon is up, too; and then for the breakfast. While clearing up the dishes the guide tells you, perhaps, about Matalic, a poor old.Indian, who formerly lived all alone near where you are encamped, - how one night two hunters, caught by a storm, found his camp, and stopped over night. He was not there; but in the morn- 
ing, when one went for water to the spring, he came upon Matalic nearly frozen. It seems his eyes had been failing for some time, and he had suddenly become blind, and could not find his way back to his camp.

Soon you start on again, with here a pool with trout to fish, now a duck to try a shot at, and each day bringing some new pleasure. If it is the right season for floating for deer, your guide will give you a chance at that. Provided with a Jack-lamp placed overhead, you sit perfectly still in the canoe, while your guide plies the paddle without noise. You listen in the dark"for any sound of deer feeding in the water, and, if heard, the guide slowly paddles up. When near, the light is thrown upon them. This shows the bright eyes of the deer, at which you should fire. If successful, it will add to your list of provisions, as well as give you experience in a new pleasure. So on day by day.

Stopping in camp if a rainy day occurs (a 
change, not uncomfortable, as a blazing fire keeps away all damp and cold), gaining strength each day, soon eager to do what at first would have seemed a task to a city man. Every living thing in the woods has a charm. The loons in the lake, the heron, the eagle, the kingfisher, the hawks, - all are watched with interest. The forest itself grows upon you; and when at length the guide tells you that the time is nearly up, you can hardly believe it possible, and you prepare to return home almost sad to think of leaving such freedom from care, and resolving if possible to return the next season. Many men engage their guides for the next trip without a thought how far off it may be.

Angling has among its disciples a greater number of scholarly and celebrated men than any other sport. In fact, it is well named "The Contemplative Man's Recreation." Many famous men of the past, as 
FISH : THEIR HABITS AND HAUNTS.

well as of the present, are well-known as fishermen. Daniel Webster was awful anxious to get away from Washington when detained over his fishing season. President Arthur has a reputation as a salmon fisherman, with a fifty-pound. fish to his credit. It was on a salmon stream that he first met Judge Gray, - a fact that, perhaps, had much to do with the latter's recent appointment. The celebrated Rev. Dr. Bethune, of New York, was an ardent disciple of Walton. Dr. John Todd, of Boston, passed many days in the woods; and hundreds of tired clergymen, lawyers, and workers in other confining pursuits look forward to their trips to the woods and lakes with an eagerness hardly describable.

The Angler's Apparatus.

It is impossible to be a successful angler without such a complete and well-arranged 
28 FISH : THEIR HABITS AND HAUNTS.

assortment of tackle as will enable you to be prepared for all times, seasons, and circumstances; and a true brother of the craft will find much to amuse him in the exercise of his ingenuity in making and repairing lines and flies, and in the orderly disposition of the materials of his art.

Of these the following is a list: Rods for salmon-fishing, trolling, spinning the minnow, or bleak, fly-fishing, and angling at the bottom, and wincles or reels for running tackle; hooks, from No. 4 to No. I 2, tied on gut, hooks, from No. IO to No. I3, tied on hair, and loose hooks of all sizes; paternos. ters for perch, shoemaker's wax and sewing silk, floats of various sizes, and caps for floats, split shot, and plummets for taking the depth of the water; disgorger, clearingring, and drag; landing-net gaff, and kettle for live fish; gentle-box and bags for worms; a fishing-basket, creel, or gamepouch, pair of pliers, a pair of scissors, pen- 
knife, a book of artificial flies, a book of general tackle.

RODS AND LINES.

Choice rods are of the utmost consequence to the angler's success ; and various instructions have been given by different authors for selecting proper kinds of wood, and manufacturing rods; but as excellent rods of every description are now to be purchased in almost every part of the United States, it is sufficient here to recommend such as will be generally useful, and may be procured without difficulty at any of the fishing stores.

In choosing a rod, be careful to examine if the joints fit securely; if it be perfectly straight when put together, and if it spring equally in all its parts, from the butt to the tip when bent. The rod for fly-fishing should be thirteen feet long, and light, but not too weak in the middle, - a fault common in fly-rods. A rod for fly-fishing should be 
30 FISH: THEIR HABITS AND HAUNTS.

light, - the lighter the better, if the strength be preserved and the action kept in the right place.

A good fishing-rod is one of the essential instruments of the angler, and the one to which he pays the greatest attention. But in remote country districts it is often surprising how necessity sharpens the intellect of the angler, and how he makes shift with the simplest and rudest implements, and really procures a good day's sport under the most discouraging circumstances.

Every person who has visited the rural districts with his rod in hand must have seen instances of this kind, and felt a sort of reproach that, with all his superior outfit, he could not hope to surpass the success of the simple but indefatigable rustic crafts. men.

The qualities of a good rod will vary much with the nature of the angling There need be no great difference between a salmon. 
rod and a trout-rod for fly-fishing, unless one fishes very wide streams or lakes in open boats; in such cases a fourteen or sixteenfoot double-handed rod is the best. A single-handed rod ought to be from twelve to fifteen feet in length, and it should be as elastic as possible. The most beautiful rods are those made of ash and lancewood; but a good lengthy rod, where it is not too heavy for the single hand, gives the angler a greater command over the water, and enables him not only to throw his flies more lightly, but often to reach distant spots, where fine fish are lying, without over reaching himself or having recourse to wading.

That which is commonly called "a general rod" will be found most useful to the trav. eller who has not an opportunity of carrying more than one with him at a time, it being so contrived that it may be used either for fly-fishing, trolling, or bottom-fishing, as the butt of the rod is bored, and contains several 
spare tips, - one for the fly, one for spinning the minnow, one for the float, and another for trolling, the whole being conveniently packed up in a canvas bag.

Although this kind of rod will be found highly serviceable, it is by no means to be recommended when one has an opportunity of employing separate and appropriate rods for the different kinds of angling. The rod used exclusively for fly-fishing should be as light as is consistent with strength; if to be thrown with one hand, it should be not more than twelve or fifteen feet long, and if with both hands, not more than sixteen to eighteen feet Indeed, a rod shorter than either of these lengths specified would be found very convenient in a narrow, closely-wooded stream, where it is frequently necessary to force the fly with a short line under overhanging bushes. Some anglers cannot be persuaded to use any other fly.rod than one composed of two pieces 
only, and spliced in the middle: but this is inconvenient to carry, and the jointed rods are now brought to such perfection that there is no doubt they will answer every purpose of the spliced rod, besides being more portable. The Irish fly-rods are screwed together at each joint, and are much more elastic than the English rods.

The trolling-rod should be very strong, and not less than twelve nor more than sixteen feet in length, with large rings upon it, that the line may run freely. The rod for spinning the minnow, or bleak, should be of bamboo-cane, from eighteen to twenty feet long, with a tolerably stiff top; the rings should be placed at a moderate distance from each other, and be of medium size.

The barbed rod, for angling with the ledger bait, should have a stiff top and be about eleven or twelve feet long; but for flood-fishing it must be made lighter and 
34 FISH : THEIR HABITS AND HAUNTS.

something longer. The rod for roach or dace should be of bamboo-cane; and, if for bank-fishing, from eighteen to twenty feet long; but if for angling from a punt, not more than eleven or twelve feet. It must be very light, perfectly taper, and of a proper - degree of elasticity, as the angler's success in roach or dace-fishing depends upon his dexterity and quickness in striking when he has a bite. Many anglers never fish without running-tackle, that they may be always prepared to encounter a large fish; but they must not hope to meet with the same sport in roach and dace-fishing as those who use a light rod, without rings, and a short line, with which the chance of striking the fish is much more certain.

The best lines for running-tackle are compounded of silk and hair of different degrees of strength and thickness, according to the purpose for which they are intended. For salmon-fishing a strong "wind," large enough 
to contain from eighty to one hundred yards of line, is requisite; and for trout a brass reel containing from thirty to forty yards of line, gradually tapering to a few hairs at the end, where a foot-link of gut holding the flies is to be fixed.

Silkworm gut lines are from two to four yards long, and are used as lengths to be added to the line on the reel, either for flyfishing or bottom-fishing. Lines for trolling are of several kinds, - some of twisted silk, and others of silk and hair; but those sold by the tackle-makers, called "patent trolling lines," are in most general use. A strong rod and from forty to sixty yards of line are needed. Indian weed is a good material for bottom-tackle, but inferior to silkworm gut. Cat-lines, night-lines, and trimmers may be purchased already fitted up.

A "wind" or reel is used for runningtackle, and is generally made of brass. The 
36 FISH: THEIR HABI SS AND HAUNTS.

multiplying reel was formerly much used, but from its liability to get out of order a plain reel without a strap is now preferred. Reels are of various sizes, containing from twenty to one hundred yards of line. The paternoster is a line used for perch-fishing. It is made of strong gut, and should be connected with a running-line by a fine stud swivel. It should contain three hooks of sizes 7,8 , or 9 , placed at equal distances from each other; the first near the bottom, where a small plummet of lead is fixed to sink the line, and the others at intervals of from eighteen inches to two feet. The hooks should be so contrived by means of swivels as to revolve around the line, and thereby give play to live minnows, with which they should be baited.

\section{Floats and Landing-Nets.}

Much care and judgment are required in adapting the float to the various streams or 
waters in which one angles. A deep and rapid river will require a float that will carry from sixteen to twenty of No. 4 shot. If the stream be deep, and the current gentle, a float carrying one-half the number of shot will be sufficiently heavy. When the water is perfectly calm, a very light quill-float, carrying two of No. 6 shot, should be used. The smaller the float is the fewer should be the number of shot; and the finer the bottom-tackle the greater will be the success in fishing. The tip-capped float is the best for pond-fishing and for gentle streams, as the line is confined at each end of the float by a cap, which enables one to strike at a fish with greater precision than when using a plugged float, which has a wire ring at the bottom for the line to run through.

In shotting a line, a number of small shot are preferable to a few large ones, as they mark less distance in the water. The line must be shotted till not more than the cap 
38 FISH: THEIR HABITS AND HAUNTS.

of the float is seen above the water, uniess the water be very rough from wind or a rapid current; in which case something more of the float must swim above the water. The porcupine-quill is a favorite float with some anglers, but for a moderate stream a swan-quill is preferable.

A landing-net may be purchased which will unscrew from a socket in the handle, into which socket a gaff or hook for landing salmon, pike, and large trout may also be screwed, and both net and gaff may be carried in the basket or creel till the river side is reached. The handle should be four or five feet long.

FLY-Fishing.

Fly-fishing is certainly the most pleasant kind of angling, and it has many advantages over every other mode. In the first place, the apparatus is light and portable; for with a slight rod twelve feet long (or, if for a narrow and wooded stream, one of ten feet only 
would be more convenient), a rod containing thirty yards of line, a book of artificial flies, and a landing-net, one is fairly equipped for the sport. In the second place, it is the most cleanly and least cruel mode of angling, as one is not obliged to soil his hands with ground-bait or live-bait, or to torture living fish or insects on his hook. Another charm in fly-fishing is that one is never restricted to one spot, but continues to rove along the banks of the stream, enjoying in his devious paths all the varieties of its scenery.

In fly-fishing these rules should be observed:-

I. Always fish with the sun before you and the wind behind you; if it should be blowing in any other direction you will be unable to cast your flies where you want them to go. Cast straight before you, allowing your flies to go with the stream as far as possible, so as to imitate the natural fly swimming. 
40 FISH: THEIR HABITS AND HAUNTS.

2. Take care to have your running-line always clear; for if there is any impediment, and you happen to hook a good trout, he will break your tackle to pieces before you can free the line.

3. The water must be clear, the clearer the better, provided the day be cloudy; it is useless fly-fishing when the water is thick.

4. Different waters requira different flies; those that may be good killers on one river may not catch a single trout in another.

Fly-making, is one of those delicate and minute matters which can be learned effectually only by imitation, _ just as a man learns to make a shoe, a bucket, a chair, or a table. One will learn more of fly-making in an hour by the eye than in a twelvemonths by the undersianding.

\section{Trout-Fishing by Dabiing.}

For this method of n̂shing, a fly-rod and finest line, with two yards of fine casting. 
FISH: THEIR HABITS AND HAUNTS. 4I

line, and a small hook, should be used. Catch one of the flies similar to those at which the trout are rising, and hook it under the belly; let the sun be in your face and the wind behind you; stand as far from the bank as you can; then drop the fly lightly on the water, and if a fish does not rise at it in a moment, lift it and let it drop again; if there is a fish about, the fly will not be dropped many times before it is seized. Be careful, when you strike, that you do not break your line. You may do good execution by poking your rod under trees or bushes overhanging the water, but you must go carefully and quickly to work or you will not have the shadow of a chance.

Minnow-Spinning and Bottom-Fishing.

The rod for spinning the minnow should be thirteen or fourteen feet long, light and not stiff. As the line is light, and the tackle fine, one is likely to break them when he 
gets a run, if he fishes with a stiff rod. Besides, trout, when hooked, sometimes make tremendous leaps, and if one leap from you, and the rod is very stiff, something will be sure to break. The line for spinning the minnow must be made of silk, plaited, one hundred yards long. Tackle for spinning the minnow, if one is going to fish in a river where the fish are large, should be made of three stout guts, not tied together, but looped to three small swivels, one at each joint, and a single hook with a small lead twelve inches from the hook. This is the very best tackle for spinning the minnow for pike and perch, as well as trout. But if you are going to fish in a small stream or brook, where you know the fish are small, finer gut should be used. The way to bait this tackle is with a fine baiting-needle, putting the needle in at the bait of the minnow on one side and out at the mouth, drawing the shank of the hook inside the bait, 
placing the bend of the hook so as to bend the tail, and stitching the mouth up with a needle and thread; the thread should be lapped round the gut to keep the minnow in place. If you are spinning for trout in a river, fish under water, - in the rapid water by the side of stone-walls or broken banks, where the river comes dashing and boiling furiously; at mill-tails, and all such places; but only fish these places when the water is clear. When there is a rise of water, and it is discolored, fish in steady, shallow places, and work your bait much, or the fish will not see it. When you see a likely spot for trout, keep as much out of sight as you can, as trout, when feeding small fry, often lie within a foot of the surface, so that they can easily see you, and if a trout gets one glimpse of either you or the rod he is off in a moment.

Spin the minnow against the stream, and if the stream is deep enough, sink the minnow three or four feet, and spin upwards, 
44 FISH : THEIR HABITS AND HAUNTS.

throw your bait as far as you can across the stream; then let it sink deep in the water without touching the bottom, and spinning to the surface. The best minnows for the purpose are those of moderate size, with their sides and bellies of a pearly whiteness. If the angler has conveniences for keeping them, they are all the better for being kept a few days in clear, soft water, as this renders them firmer and brighter. The twisting of the minnow is the beauty of this kind of angling; the fish, seeing it at a great distance, fancy it is making all the haste it can to escape, and they make more haste to catch it.

Bottom-fishing with the worm is decidedly an excellent mode of angling for trout. I have caught trout with the worm when the fly and minnow could not capture a single fish; and when it is done rightly, this method cannot easily be surpassed. If the water is clear, and you are to fish in a brook or small 
FISH: THEIR HABITS AND HAUNTS. 45

stream, the most likely places are under bushes, by the side of piles, under old trees overhanging the water, or under anything that can form a cover for trout. Sit down very quietly ten or fifteen yards above the place you have selected for fishing in. If the stream is shallow opposite where you sit, and then falls into a hole, all the better; get the right depth by trying, and then adjust the quill-float so that the bait will just miss the bottom; cut two or three worms in short pieces and throw them in some yards above you, and if the water is five or six feet deep they will go to the bottom below you, just where you want them; put your bait on, and then let it go down the stream, giving out line from the reel until the float is - under the bushes. The trout will bite, one after another, without fear, and you can soon fish out all there are in the hole. 
46 FISH : THEIR HABITS AND HAUNTS.

\section{BAITS FOR TROUT.}

The natural bait most generally used in angling is the worm; it may be used successfully for every kind of fresh-water fish, with the exception of pickerel. The lob-worm is in season from May to September, and may be found at night with a candle or lantern in any place where the grass is short. It is an excellent bait for salmon, trout, and eels.

The red worm is small, and of a bright red; it is found in old manure heaps, in decayed tanners'-bark, and on the borders of old drains; it is impossible to speak too highly of the value of this worm to the angler, as almost every kind of fresh-water fish will take it eagerly.

To bait hooks with worms enter the point of the hook a little below the head, threading the worm carefully without breaking or bruising it to within a quarter of an inch of the 
FISH: THEIR HABITS AND HAUNTS. 47 tail; the shank of the hook must be well covered with the worm.

An angler should always be provided with well-scoured worms, as they are more lively, bright, and tough than when first taken from the earth. There are various modes recom. mended for scouring worms, but the use of clean moss alone will answer every purpose. The moss should be well washed and squeezed till nearly dry, then placed in an earthen pan to receive the worms, which will be ready for use in four or five days. Great care must be taken to keep the moss sweet and clean by changing it every three or four days, and washing it well, and if any worms are dead they should be removed.

The grasshopper is found in short, dry grass in the months of June, July, and August, and is an excellent bait in bushfishing. 
48 FISH : THEIR HABITS AND HAUNTS.

SALMON.

The salmon is the noblest of fresh-water fish, and stands highest in the angler's estimation. He is the king of the streams; his title to precedence has never yet been questioned; his magnitude, his keen and lively eye, his shining silvery scales, his muscular powers, his rapid and graceful motions, his beautiful proportions, his intellectual instincts, and his rich, delicate flavor, all unite in establishing his superiority over all other fish. Neither should it be forgotten that salmonfishing is considered the angler's highest sport, whilst it affords the best criterion of his professional skill. Indeed, success in angling for this noble fish may be deemed the measure or standard of the angler's dexterity, - the test of his art, the legitimate object of his loftiest aspirations, affording undeniable proof of his fitness to take his 
stand amongst the most accomplished adepts of this interesting craft.

The salmon spawns generally in the months of September and October, but there is some difference in different rivers. It is at this season that it is seen passing up the river in enormous shoals, and leaping over every obstacle which lies in its way. When the salmon takes the fly the angler must immediately give him time, and must particularly bear in mind that the slightest rashness at this crisis will set him at liberty again. No matter how well-seasoned or strong the tackle may be, no one can succeed in turning a salmon when he is first hooked. It is only by giving comparatively gentle tugs, or letting him feel the weight and pressure of the rod and line at short intervals, that you can make him rush about backwards and forwards so as to exhaust his strength. The greatest patience and coolness are therefore indispensable. Many fish 
50 FISH: THEIR HABITS AND HAUNTS.

will require unremitting care and skill for two or three hours before they yield; and few of any size can be landed as they ought to be in less than an hour. When the fish bounds repeatedly out of the water the chances are that he will succeed in breaking his hold either by the main force of his fall into the stream, or by tumbling across the line. The latter accident scarcely ever fails to set him free. When the fish takes what is called "the sulks," the chances of killing him, if the bottom is not favorable, are very problematical.

A salmon will rise again and again at the fly after he has missed it. In this he differs widely from the trout. He has been seen to miss the fly a dozen times in succession, and at last take it greedily. Should he, however, be slightly hooked in any instance and break off, he will come no more, - at any rate not for some time.

It is important for the angler to be able to 
FISH: THEIR HABITS AND HAUNTS. 5I

detect with a glance of the eye the places where salmon may with most probability be expected to lie. It is not often that he is to be found in long, straggling streams comparatively shallow, and not leading directly into a longer or shorter reach of deep, still water. $\mathrm{He}$ is always very shy of trusting himself in such places. On the contrary, a rapid stream, running directly into a sheet of deep and still water, is his most probable haunts. Many large fish, however, never go into the stream at all; they keep in deep water among large stones, brushwood, and old sunken roots of trees. When, therefore, there is a fine brisk curl on the surface of the water, and it is otherwise in good condition, the deeps are the place for finding fish. The shallow end or tail of a good long deep, where there is a broad bed of grander slopes, is in all salmon rivers a favorite spot for fly-fishers.

The building of dams and manufacturing 
52 FISH: THEIR HABITS AND HAUNTS.

establishments, by preventing the fish from going up the river to deposit their spawn. has almost annihilated the salmon in this State. Forty-five years ago it was very abundant in the Merrimac river. Now the very few specimens taken are looked upon as curiosities, and our market is supplied by the Kennebec and St. John fisheries.

\section{Blue-Fish.}

This fish is a species of mackerel, and sometimes passes under that name. He has his peculiar grounds in the rivers and bays, where he comes in schools from the ocean during the months of June, July, and August, after which he returns to the ocean for the winter. He is taken only by trolling, either with a bait of fish or with the artificial squid. Trolling of late years has become a favorite amusement in this country, and the blue-fish affords to those who live in the localities he frequents much pleasure. Troll- 
ing is usually done from a good-sized boat, with a guide who knows the ground, or else by casting from the shore and drawing in repeatedly. The former method is the most common.

The tackle is simple, cheap, and easily arranged. It is composed of a squid of bone, tin, or pearl, with a stout line from one hundred to one hundred and fifty feet long. From the boat while in full sail the squid is thrown out, the fish hooked and drawn in, and the squid thrown out again. It is a good idea to have a length of wire or stout gimp between the squid and line. Often in such excursions a squid is lost at a time when a lover of this sport can least afford time in making the necessary repairs to his damaged tackle. The line should be of cotton, large and well laid, from forty to sixty yards long; a light line will not answer, as in case a large fish is hooked there is more than an even chance that the line 


\section{FISH : THEIR HABITS AND HAUNTS.}

will part before he is secured, and should the fish be got in, the fisher's lacerated hands will remind him that there is more comfort in trolling with the regular squidding tackle. With a good boat, a guide who understands the locality, and a fine breeze of four or five knots an hour, one may be pretty sure of good sport. Having thrown out his squid with one hundred and fifty feet of line, he ties the end of the line securely to the boat, as the fish sometimes strike with much force, and neglect to fasten the line frequently results in the loss of the whole thing. When a school of fish is found, the boatman should be particular in crossing and recrossing the spot where the school is, as it frequently happens that the most sport is had within narrow limits. When the fish is struck the line should be hauled in with a steady pull, not jerked; if the line be allowed to slack the fish is apt to throw itself off. To disengage the fish from the hook, take the squid 
FISH : THEIR HABITS AND HAUNTS. 55 in the right hand, and give it a slight shake with the hook uppermost, and the fish will drop off into the boat. The most favorable plaçes for .blue-fish are Buzzard's Bay and Wareham, on the Cape; also Babylon, Inslip, and Quogue, New York. Babylon and Inslip are near New York City, and are easy of access.

\section{Black-Fish, or Tautog.}

The name of this fish is derived from the color of its back and sides, which are a bluish or ebon-black. The black-fish abounds in the vicinity of Long Island, and is a constant inhabitant of salt-water. It never visits the rivers, like the salmon, nor deserts its dwelling-place. It is fond of rocks, reefs, and rough bottoms.

Until within a few years the black-fish was not found north of Buzzard's Bay, but it will now be found in Massachusetts Bay. It is a fine table-fish, and is well known to all 
56 FISH: THEIR HABITS AND HAUNTS.

epicures. It affords much amusement for anglers. It is taken on reefs or about detached rocks, where the food in which it delights is found.

The usual baits employed in taking blackfish are the hard-shelled and soft-shelled clam, the rock-crab, and soldier-crab or fiddler, the shrimp, and shedder-lobster or crab. The last two are decidedly the best that can be used. There is a very great difference observable in the black-fish, even in those fceding together at the same rock. Those taken close to the rock are shorter, darker colored, and thicker than those which are found playing in the edge of the tide as it sweeps past the rock. These are long, with large heads, and of a light color, especially about the head and snout, the latter frequently being nearly white; whence they are called white-noses and tide-runners. They seem to delight in the eddies at the very edge of swift water, where they watch for 
FISH: THEIR HABITS AND HAUNTS. 57

the shrimp or crabs which are borne along by the tide. You should cast the line a little above the rock, and let the bait float with the current past it. Holding the rod with an even, ready hand, you present the bait to his expectant eye in the most natural way; and to do this should always be the study of the angler who wishes to succeed.

The best mode of arranging rod-tackle for black-fish is this: attach two plaited gutsnells, one of twelve inches and one of. eight inches, to a small brass ring; put a slide-sinker on the line, and tie to the ring, and all is ready. The slide-sinker is by far the best, as it is frequently desirable to throw from a boat to a sunken rock, and as the sinker lies on the bot tom the sinallest action of the fish at the bait is readily felt. When the black-fish favors you with a bite, give particular attention and pull quickly, for he has a hard, tough mouth; and if your hook and tackle 
58 FISH: THEIR HABITS AND HAUNTS.

are strong you need not be fearful of any damage to your tools, and with proper care you can call him in. The black-fish weighs from one to ten pounds.

\section{MACKEREL.}

On our coast the mackerel is taken in nets in small numbers from the latter part of May until about the Ioth of June. After this it may be readily taken with the hook, and is brought to market in large quantities. Although as fresh fish mackerel are sold in our markets along our whole coast for several months of the year, and are considered by all excellent food, their greatest value arises from the employment they afford to an immense number of persons by the process of salting and packing, - the number of barrels inspected in Massachusetts each year being about two hundred and fifty thousand. In some years immense shoals of mackerel are readily met with, and vessels return from fish- 
ing-trips in a few weeks with full cargoes, while the same localities may be visited in other years and the efforts of the fishermen prove fruitless. So peculiar are the habits of this fish that oftentimes weeks may pass, the fishing-smack be surrounded by millions of fish sporting upon the surface of the water, and scarce one will allow himself to be taken; while, again, the success of a few days will retrieve the disappointment of nearly a season.

\section{Scapaug-Scup.}

This fish is taken in large quantities in Buzzard's Bay and Martha's Vineyard Sound, but it had not been met with in Massachusetts Bay until within a few years. It has latterly been found at Buzzard's Bay and Holmes' Hole. It is one of the most common species in the harbors, and is used more than any other fish when fresh. At the latter place it is taken from the Ist of June 
60 FISH : THEIR HABITS AND HAUNTS.

until the middle of October with the hook; after that date, in the ponds, with nets and spears.

\section{Commox Shad.}

This excellent species is brought to Boston market from the mouths of the neighboring rivers in considerable quantities in the spring of the year, and meets with a ready sale. Shad and alewives go up the rivers during the month of May. Their usual weight is from one to four pounds.

\section{The Perch.}

The perch is second only to the pike in boldness and voracity. $\mathrm{He}$ is gregarious, is an inhabitant of almost all the rivers, lakes, and ponds of the United States and Europe; he is the delight of the young angler, as he bites at all times very freely at nearly all kinds of bait offered him, and is to be caught with the most humble kinds of tackle. As he swims in shoals, twenty or 
FISH : THEIR HABITS AND HAUNTS. 6I

thirty of them are sometimes taken in a short time in one spot. But there are times and seasons when it is past the angler's art to tempt the perch to feed. The middle of the day in summer is very unfavorable; and, as a general rule, the best time for angling for them is from sunrise to eight o'clock in the morning, and from four o'clock till dark in the evening.

The season for fishing perch is from August till March. Its flesh is very firm and white, of excellent flavor, and particularly wholesome and easy to digest. Mr. Yarrell says: "The perch, though common, is one of the most beautiful of our freshwater fishes, and when in good condition its colors are brilliant and striking. The upper part of the body is a rich greenish-brown, passing into golden-yellow; the first dorsal fin is brown, the membrane connecting two or three of the first and last rays spotted with black; the second dorsal and pectoral fins, 
62 FISH: THEIR HABITS AND HALNTS.

pale brown; ventral, anal, and caudál fins bright vermilion." A perch of three pounds is considered large, but it has been taken weighing six or eight pounds. The perch loves to lie by the side of the stream, and under deep banks or near beds of the waterlily, the eddies at milltails-tide, and tumbling bays, near old piles of wooden bridges or old kemp shedding, as well as under projecting willow boughs. The best baits for perch are the minnow, the gudgeon, the red worm, and the brandling.

The common mode of angling for perch in ponds is with a light, stiff rod, similar to that used in worm-angling for trout, with a short line of about the length of the rod, a light float and a small sinker, with trouthook No. 2. The usual bait for the perch in pond-fishing is the common groundworm, which it will take generally, if it will take anything. In regard to minnow-fishing for perch, Hoffland says: "The minnow 
FISH: THEIR HABITS AND HAUNTS. 63

may be used by fixing a No. 9 hook under the back fin, or by passing it through his lips, with a cork float carrying shot accorting to the depth of the water. You should fish within a few inches of the bot. tom; and when a fish bites, a little time should be given before you strike, as the perch is tender-mouthed, and if not well hooked is apt to break his hold."

In concluding these remarks about perchfishing, it is proper to describe a means of attracting the fish, which is not generally known. It is a secret of such value to the fisherman that he ought to feel amply repaid for perusing these pages when he comes upon it.

Procure a large glass bottle, like those seen in the windows of chemists, - the clearer the glass the better; fill the bottle with river water, and put into it a quantity of live and lively minnows; cover the top with a piece of parchment with holes punctured in it; 
64 FISH: THEIR HABITS AND HAUNTS.

and tying a strong cord about the neck of the bottle so prepared, sink it near a pile in a river, or in a deep hole near the bank. This should be clone early in the morning or late in the evening, when no one is about to witness the operation; conceal the cord and the bottle for two days. At the end of that time drop a paternoster baited with live minnows by the side of the bottle, and you may be sure of excellent sport, as the sight of the minnows in the bottle will have attiacted numerous perch to the spot.

\section{The Smelt.}

The body of the smelt is long and slender; the color of the back a pale green, and the belly a silvery white; the scales are oval and small, and fins are all of a yellowish white. The smelt is remarkable for its pleasant and peculiar smell. It spawns in March or April, and inhabits the fresh-water from August till May. After spawning it returns 
FISH: THEIR HABITS AND HAUNTS. 65

for a time to the sea. It feeds upon insects and small fry, and is very fond of the shrimp. . It seldom exceeds seven or eight inches in length. In fishing for smelt sometimes' the paternoster is used as in perchfishing, baited with live shrimp or a small bit of a smelt. It is generally taken in deep water about our wharves, from August to December.

TRIP to Kempt, N.S., IN I 879. - A Moose HunT.

I left Boston on the morning of September I th, at eight o'clock, and had a nice, smooth passage and a fine rest. I arrived in Portland at 4.30 P.M., and soon left for Eastport, reaching St. John at four P.M. on the I 8th. I stayed on board till the next morning, and then took steamer "Empress" at eight o'clock for Annapolis, and arrived there without much worthy of note. At Kempt I met by appointment my guide, 
66 FISH : THEIR HABITS AND HAUNTS.

and stayed over-night at his house; and let me say just here, a better guide and woodsman, a keener hunter and honester man than my guide, David Freeman, cannot be found.

We started with baggage for the lake at ten A.M. of the 2oth, and camped that night at Puzzle Lake. In the morning we commenced to call for moose; the moose answered, but did not come up, so we pulled up camp, and tramped through the clear, cool morning to the foot of Progress Lake. We did not attempt calling moose again, as our natures demanded rest. However, I pulled out a rod, and caught three trout weighing. fifteen pounds, which were soon cooked and eaten. After a nice night's rest, only broken by the owl's terrific screech and the lonely call of the loon, we left our traps and went to the west side of Long Lake to call; but it proved to be a bad night, stormy and windy. On Wednesday we went to Long 
FISH : THEIR HABITS AND HAUNTS. $6 \dot{7}$

Lake. This region abounds in beautiful lakes, where there is fine fishing and hunting. In the morning I fished Shelburne river, but the water was very high, so there were few fish. The wind was high, and there was no calling for moose, so we, gave up for the night, which was very cold, making frost and ice. Next morning we started for Irving Lake, some miles distant, but there was no show for moose, with the wind blowing great gales, so we went down Shelburne river to Sandy Lake, which took five hours. Here fishing was good and the scenery delightful. However, our object was not yet achieved, and once more we returned to Irving Lake, arriving late in the afternoon, very tired; but the wind had gone down, the air was perfectly still, and David said that this was the time. He made a horn of birch, and uttered a low, plaintive cry, and to our great delight a moose answered our first call, and came slowly up. 
About half-past six the sun had gone down, and the moon was hardly up, with a dense fog over the bay; still the moose came on slowly. We were concealed by bushes, lying flat on the ground. $\mathrm{He}$ advanced to within thirty-five yards. I fired my first shot, which struck him on the head, but to feel sure I shot once more, struck him in shoulder, and dropped him. He proved to be a large, fine bull, with handsome horns. We opened him at once, and returned to our resting-place for the night, well satisfied with the undertaking. Our journey was well repaid to see this noble animal and know that the desired object had been gained. Next day, October Ist, at five in the morning, we skinned the moose, David taking the skin for hunting-shoes, after he had dried and tanned it. We covered up the meat, and at nine o'clock started for help, expecting to find two men getting out shingles some five miles from us, but 
FISH: THEIR HABITS AND HAUNTS. 69

they had gone. So we continued out of the forest to Kempt, where we arrived at nine o'clock in the evening, after a day of hard but most healthful work. The next day we returned to the lake to see if our meat was all right, taking with us two extra men. We arrived at six in the evening, too late for work. October 3 d, we cut up the meat, and found that our animal weighed between seven hundred and eight hundred pounds. We loaded canoes and started for Kempt at nine in the morning. We spent the night on Big Carry, and reached the landing at twelve o'clock. After dinner David and the men started for home. I, being very tired, found a good place and pitched camp and got all housed for the night. At some time in the small hours David returned, and in the early morning we started for Eel river, where we arrived about eleven in the forenoon. Here we found partridges in great numbers, also plenty of fish. We went down the river 
70 FISH : THEIR HABITS AND HAUNTS.

and did some fine fishing; shot a nice mink, the skin of which David stretched on three sticks, as I had promised A- she should have one; and in the afternoon hunted partridges. Tuesday, October 7 th, we started for Kempt, arriving at five in the afternoon. The morning of October 8th was beautiful, and David drove me to Digby, stopping for breakfast (a good one it proved, our appetite being keen after our long ride) with his sisters, who own a fine farm. We reached Digby at two, and spent the night at Lord Dufferin's house. Next morning I took the boat for St. John on my way home. I had a very fine trip, with good weather. So ended my first moose hunt, - a trip never to be forgotten for my success both in hunting, and fishing, and for the beauties of the country I saw. 
FISH : THEIR HABITS AND HAUNTS. 7I

Trip to Nova Scotia, Sept., i $88 \mathrm{r}$.

I left Boston at 8 A.M., September 26th, on steamer "City of' Portland," and reached Portland at half-past four o'clock, after a good, smooth passage. There were very few persons I knew on board, so I took to my state-room for a' long nap. We had a fine run to Eastport and St. John. I spent the night at Hotel Dufferin, and made a few calls on friends. In the morning I took a steamer to Annapolis. It was very foggy, but the water was not rough. I found Freeman at the wharf waiting for me. We soon started for his house, where we arrived at ten in the evening. This was a quick run from Boston into the forests of Nova Scotia. On the 29 th we started for the lake. We built a fire and had dinner at the landing. A man and boy helped us across the lake and the lonely carry. Having left them we went to Mount Lake to call. It 
72 FISH: THEIR HABITS AND HAUNTS.

was a fine night, but we had no answer and so gave it up. We arranged our apartments for sleeping behind a big rock, and, strangely enough for the first night out, slept well. In the morning we went back to the carry, and found all our things at the shore; but the man and boy were gone. We loaded all into a canoe, and it was a very heavy load; but how much these canoes will carry when filled by one who knows just how to do it, is astonishing.

We reached Pisquaw Carry at noon, and found John Freeman and five men logging. John came down and helped us with our things, and had us take dinner at his camp. The bill of fare consisted of baked beans, bread, and tea. How good it did taste! Before we left our camping-ground he came up to our camp with a very bad cut in his foot; a twig had made the axe glance. If an old chopper like this cuts himself it is a warning to us green men to be very careful. 
FISH: THEIR HABI'S AND HAUNTS. 73

We started from there at two P.M., and had one more carry into Pippy Luggage Lake, and then, with high water, had a very fine run into Irving Lake. I hope some of my many friends may be induced to make this trip; they will be well repaid. Freeman would be glad to see them at all times; he would make their stay pleasant. We camped in a new spot, well protected from storm and wind, with a good lookout through the trees up the lake. We had some rain in the night and plenty of wind. The thermometer stood at $65^{\circ}$, and there was a good bracing air. It was the best camp I ever had, and I slept as only a tired man can sleep. October Ist, we did not breakfast till half-past eight. The wind was strong, but it was warm, the thermometer making $68^{\circ}$ in the shade. I felt well, but lazy, and decided to stop here and enjoy the sweet smell of pine and spruce as well as the delightful prospect, until the wind should go down. Haly, of 
74 FISH: THEIR HABITS AND HAUNTS.

California, was here one day before us, and this made our chance of success rather less than we had hoped. This morning I found plenty of trout-bones, and concluded to try the river. In the afternoon we fished a little, getting some fine fish. We went to the bay, but there was so much wind it was of no use. We camped under rubber blankets and were very warm. Next morning the thermometer registered $55^{\circ}$; the wind was northwest; it was cloudy. We had a nice breakfast of baked beans warmed in tin-pan in ashes, boiled potatoes, coffee, and toasted hard-bread. What appetites the out-door life brings to us poor city chaps, who see nothing but brick walls the most of the year! How little we know the beauties of Dame Nature's book!

I fished in the afternoon for a few minutes, and caught six nice fish. I also shot a partridge that had ventured near the camp. The wind went down towards night, so we 
FISH: THEIR HABITS AND HAUNTS. 75

went to the bog to call for moose. It was a fine night at first, but we had no answer. Before morning it rained hard, so we started back to camp. We cut plenty of wood, and had a good fire and breakfast, but grew tired of waiting for clear weather. I did plenty of sleeping this trip, as rain continually followed me. It turned very cold, so we put up shelter around the front of the camp, and tried to be comfortable. At last the wind and rain ceased, and the moon - almost full-greeted us; a welcome sight. We concluded to go and call on Irving Lake. There was a light 'wind blowing towards us, and after a while we got a faint answer in the long distance from Moose Lake. We again called. The answer came from nearer, and showed the bull was with a cow. In a little while both answered our repeated call, and were moving with the wind down on the other side of the bog in the woods. We moved along on one side, and gave an occa- 
76 FISH: THEIR HABITS AND HAUNTS.

sional call, waiting for an answer. We kept this up for about a mile, when we got to a place where the trees nearly met in the bog. There we crossed, and found we were ahead of them, with the wind towards us. While waiting for an answer, or some sound to break the great stillness, I saw a dark object fifty or seventy-five yards distant from me in the thick trees moving along. It fairly made my hair stand on end. I made up my mind to fire. As the darkness was great, I fired as near the shoulder as I could aim through the trees. While I put down another shell with bullet, David ran ahead and fired, as we could not see what the animal was, and the moose, for such it proved to be, dropped. My first shot was fatal, but of course David did not know it. With both guns unloaded, we went up to it; I cut its throat. As I stood up on a stump I saw another one not thirty yards off coming up. I reached my gun, and got in the last bullet I had. 
FISH : THEIR HABITS AND HAUNTS. 77

The moose saw me, and turned quickly to run. I fired at the neck, and he dropped instantly. I hardly understand how the shot could be so fatal, as the animal proved to be a bull, although with small horns. So in one minute after seeing them we had two fine moose, a cow and a bull, twelve hundred pounds of meat, and the grand object of the trip accomplished. Pretty good for only nine days out, and a Boston boy at that! David cut the throat of the bull, and placed the animals so as to bleed freely. I laid myself down to get a long breath. We started back to camp, as it was now broad daylight. At five in the morning, after breakfast, we went to John Freeman's logging camp, arriving there about noon. He was not there, but his head man and four others took their large boat and returned with us. We landed and reached the game about four in the afternoon. Having skinned, cut up, and packed seven loads of meat that night, all 
slept in our camp, and we had a jolly night of it. At half-past five in the morning all but myself went after the remainder of the meat. I packed up our traps, cut some wood, and started a fire and got breakfast.

We had a fine trip in the birch to Freeman's camp, where we left most of the meat to be salted for winter use. Then we started (amid many cheers from the loggers for our present, and good wishes for future skill and game) for Sargent's camp. We had more wind, but reached there all right at four in the afternoon. We fixed camp, and had fine moose-steaks for supper, which David knew just how to cook, and I how to eat. It was so juicy, - my mouth fairly waters now at the thought! Then we turned in for a wellearned rest. At five o'clock next morning we awoke. It was Sunday, September gth, a fine day, with the mercury at $65^{\circ}$. David went out home with the rest of the meat, leaving me alone for a day and a half; but 
FISH : THEIR HABITS AND HAUNTS. 79

not alone, for I had all nature to commune with and pleasant thoughts of home and friends. But I was not to be left even thus much alone, for three of Freeman's men came to see me, thinking I was lonely, and remained to dinner. We passed the time pleasantly, and they left early in the afternoon. I walked about a little while, and then got supper and turned in. On Monday, October Ioth, the thermometer registered $40^{\circ}$, and there was some wind. I got my breakfast, cut some wood, and loafed until noon, finding myself somewhat tired from the long tramp and the excitement of the moose-shooting of the last few days. For my dinner I made an omelet and fried some pork and potatoes. I was pleased to find myself quite successful and handy at cooking. My journal of this date says: "Seven P.M. No David yet; think there was too much wind. This camp is in a beautiful spot, tall hemlocks all around it, 
80 FISH: THEIR HABITS AND HAUNTS.

with fine green tops; quite a change from the birch woods we were in at Irving Lake. I feel how much every man degenerates without frequent communion with nature. The forest itself has a charm which grows upon me. Selfishness, ambition, and care have here no place, and a man is most truly thrown upon his own resources to be alone with nature. Reverence for and appreciation of the beautiful are elements which enter into the character of every true angler; but I. must stop, for here comes David and John Freeman, with three other men; have had a hard time to get here, - rain, wind; they were most exhausted, and very glad to find warmth and shelter."

Tuesday was stormy. We fished some, and got seven fine fish. We also hunted partridges, but there was too much wind, and we did not see any. It still was cold and stormy.

On Wednesday, the I2th, the thermome- 
FISH : THEIR HABITS AND HAUNTS. 8r

ter registered $32^{\circ}$. Still it was a fine day to go over all the lakes. We packed up and started at eight A.M. Got to Jim Challes' place, where we had dinner. We shot four partridges and saw more, but the cover was too thick to get them. We arrived at David's home at five in the afternoon.

Early Thursday morning we started for Annapolis. How hard it was to say goodby for at least a year!

Just here let me give David's recipe for cooking a sirloin of venison, - a receipt not to be despised. One must understand it to succeed well. Two crotched sticks are set up before the fire, and at the height of six feet another is laid across them; the meat is suspended by a string to the crossbar, close enough to the fire to roast, and is kept constantly turning, so that all sides get an equal amount of heat. It should be constantly basted with the rich gravy that drops from it while roasting. 
82 FISH : THEIR HABITS AND HAUNTS.

A Day on Grąnd Lake Stream.

A party of two left Boston at eight o'clock one Monday morning in June in the steamer "New England," Captain Winchester, for Calais. We had a fine trip to Portland, where we stopped about an hour. Arriving at Eastport, we left the steamer and took the river boat called the "Queen," for Calais. We reached Calais at three on Tuesday afternoon and remained over-night. Next morning we went by train to Lewy's Island, - a ride of forty miles. There we found our guide, one of the best, - an Indian of the first class named Piel Tomah (since this trip I have had as guides his two sons, of whom I shall speak later), and our cook, with twe canoes for us. We bought the more bulky articles needed, such as pork, potatoes, meat, and eggs, and embarked upon the waters of Big Lake. This lake is about twelve miles long, and we much en- 
FISH : THEIR HABITS AND HAUNTS. 83 joyed paddling across in the light canoes. We varied the pleasure by making a call upon the Indian settlement on White Island, where we found a church and some other signs of civilization among the inhabitants. Most of the women were engaged in basket. making, and were very expert. We left orders for some baskets to be ready when we should return. The men were mostly busy in the woods cutting knees for boats, for which there is quite a demand. Those we saw at home were building canoes, and afforded us an opportunity of examining the process, which is ingenious enough. We arrived at the foot of Grand Lake Stream at three o'clock, where we found a farm owned by a Mr. Gould, whom we hired to carry our bag. gage across the three-mile carry. The road was very rough, but his horse seemed to know every rock and stump, and at five o'clock our baggage was on the ground near the dam. We selected a good location for 
84 FISH: THEIR HABITS AND HAUNTS.

our tent, and soon had it pitched. Leaving our guide to arrange matters, we put our rods together and tried the fishing. We found the insects very annoying, and were obliged to use our veils and gloves; thus protected we soon raised a fine fish of the salmon tribe. After several desperate plunges his strength became exhausted and he was captured. The scales put him at three and onehalf pounds, - a very good beginning. This fish resembles the salmon so closely that most people call it the dwarf salmon. It seldom weighs over four pounds, and averages two pounds. We caught before dark some ten or twelve fish, - none, however, so large as the first one taken. The most successful fly was a small salmon-fly, with mixed yellow and red body. A fish cooked for supper proved to be delicious. 
FISH: THEIR HABITS AND HAUNTS. 85

Two Days at Skiff Lake.

With my friend I left Boston for Vanceboro and McAdams Junction on the Eastern road. We had a quick trip and a good one. Our place for camping was an old hut left by some long-gone loggers. We made ourselves comfortable, having more company than we had expected. On Monday, we went on a tramp to Medea Lake. The water was too low for fishing. On our way to Grass Lake we passed through a pasture, where we shot five partridges. We also shot six ducks, one black and the rest red teal. They made a fine dinner. On Tuesday we shot three partridges, and caught thirteen pounds of salmon and eleven pounds of trout. We went to see if a bear-trap we had set was sprung, and found a very large loup-cervier caught by the foot. He was frantic with rage. At first sight we thought it was a large dog, but soon saw our mistake. J. 
fired his revolver and killed the animal by a good shot in the head. We tied him up and started home, to find that a trapper had stolen our mink from the trap. We built two new traps, and returning home skinned our game, which was quite an interesting operation. We made a stew of ducks, which was the best yet. They were very fat, tender, and delicious. Space forbids me to speak of the fire, which so nearly consumed our tent and the nether garments of my companion. Fortunately, he was provided with another pair.

TRIP to Schoodie LAKe - A ReminisCence of the Summer of I882.

Musquash Lake, one of the chain of Schoodie Lakes, is situated in the town of Waite, Washington County, Maine, and is reached by cars from Boston via Eastern and European roads, and by stage. One warm evening in September, I882, a small 
FISH : THEIR HABITS AND HAUNTS. 87

party might have been seen wending its way to the Eastern station, cn route for the hunting-grounds of Maine. After bidding our friends good-by at $\mathrm{C} \longrightarrow$, we left for Bangor. As we entered the car great was our surprise to find nearly all the occupants of the sleeper were friends and acquaintances, bound, as we soon learned, on pleasure excursions, either for fishing or gunning. Without further incident, beyond the usual discomforts of a sleeper and of heavy clothing, we arrived in Bangor.

The weather was not inspiring when we left the car at five in the morning. It was cold, dreary, and damp. We took a carriage for the hotel, breakfasted, and left as soon as possible, not forgetting to purchase on the way a Bangor " umbrell," which ever after proved a source of amusement to at least two members of our party. At seven A.M. we again started for the further East, whither with mingled sunshine and rain, and 
88 FISH: THEIR HABITS AND HAUNTS.

accompanied by many of our friends of the night before, we journeyed on until we reached the Forest Station, not so named for forest-trees, - as a place more void of natural beauty or sentiment never existed.

Here our trouble began. As our expected van for the baggage did not appear, our little stage-driver, who seldom if ever gazed upon so much baggage for one party, was entirely at a loss what to do. Finally, deciding to leave the larger portion, we mounted the two-horse wagon, otherwise called stage, a party of six. The gentlemen of the party did duty in holding on the trunks, while one lady grasped all the bags in her reach. As we mounted the steep hill the rack gave way. Alas for pickles and trunks! What would then have become of us, had I not had the never-failing string and wire to mend the poor broken-down wagon. The baggage was soon readjusted, and we all took seats as we could find them, - a merry party, in spite of 
FISH : THEIR HABITS AND HAUNTS. 89

mishaps. We arrived at Jackson Brook, and went to the house of Mr. Dudley, who is a good landlord, and tries in every way to make it pleasant for his guests. There, too, good guides can be procured. We found a nice dinner, and did full justice to it; after which Mr. Dudley provided us with a com. fortable wagon, two good horses, and a talkative driver. We keenly enjoyed our sixteen-mile drive over a good but unfrequented road, through beautiful woods, with here and there a farm-house, having a piece of stove-funnel for a chimney. At Waite, about six P.M., we ended our journey for the night: We were warmly welcomed by the host and his daughter. Warm fires were kindled, and at once we began to feel at home. Supper followed. "What delicious milk!" was the cry, and all echoed it.

Having written home, we went to bed, tired travellers, to dream of camp and woods. But there was no sleep, for Pluvius reigned. 
90 FISH: THEIR HABITS AND HAUNTS.

Thunder, lightning, rain! Was such thunder ever heard? Wednesday morning found us detained by a pouring rain-storm. We were told "no woods to-day," and so it proved; but one gentleman, after arraying himself in woods' attire, mounted the large wagon, already filled with baggage and camp supplies, for a five-mile drive, or rather walk, through the woods. We bade him a sorrowful good-by, as we, too, wanted to see the beginning of camp-life. We watched the clouds all day, but the rain still poured; but we passed the time very pleasantly with work. Thursday morning, the clouds still hung heavy, but at seven o'clock our charioteer appeared for us, in spite of the fog. With plenty of straw, and a few bags for ballast, we took our seats and made ready for the worst ride we had ever taken. As our host had told us, the road was nothing but rocks and rocks, as any one who has been over a logging road knows. The first mile 
FISH: THEIR HABITS AND HAUNTS. 9I

through pastures was soon passed; we en tered the woods' road, and although it was early morning the fog made it very dark. Pen could not tell its roughness; but bruised bones and tired nerves were a forcible language. Glad were we to see our friends, and in canoes. They soon landed, and were formally introduced to our Indian friends (for so they proved to be). A nice dinner in the open air was speedily got for us, of which we were glad to partake. The Indians soon built a fire in the cleft of a rock, and made delicious coffee, which from the tin dipper tasted like nectar. Also we had corned beef, hard-bread, and a four-pound salmon caught by trolling on the passage down. After bidding our driver good-by, we stepped into the canoes for our first ride. How delightful we found them after our hard ride in the cart! It was like a cradle, so quiet and so restful to our tired nerves. After an hour's paddling we reached the 
92 FISH : THEIR HABITS AND HAUNTS.

head of the lake, which was to be our home for a short time.

We had hardly reached camp when the rain began to pour, but we were safely housed, and so did not mind it. We found our new quarters all ready, and nicely arranged for our comfort. This was a novel experience, our first night in a woods' bed. The hemlock boughs were nicely arranged, fragrant and fresh, but not soft. We slept well, and awoke refreshed.

Our cook was all that could be desired, and during the weeks that followed he never failed to give us the nicest the larder afforded. Friday was spent in-doors, as the rain fell in torrents, but the time passed rapidly with work and reading. Occasionally one of the guides would appear and give us his views of the weather. So also passed Saturday. Our gentlemen went out for some fishing, but were glad to return to the shelter of the tents. Sunday was spent in 
FISH: THEIR HABITS AND HAUNTS. 93

letter-writing and reading, the rain still falling in such sheets that to go out was impossible.

In the evening we were astonished by hearing low sounds of chanting; and listening found our guards were chanting a mass, they all being good Catholics. It was so unexpected that we were completely surprised as well as pleased.

On Monday the sky at last began to clear, but the sun did not shine. J. and I took our first walk around the beach, up into the cove. We found the mink trap, and were well pleased with our surroundings. L. went for some fish, but not many were disposed to bite that morning. On Monday the dog started up a deer, and never came back; not liking his quarters, he ran home.

Tuesday L. and J. started for Pleasant Lake, a long and tedious walk; but they accomplished their errand, after having tramped twelve miles. They returned tired 
94 FISH: THEIR HABITS AND HAUNTS.

and hungry at nightfall. Wednesday the hunter of Pleasant Lake appeared with two fine dogs, and after breakfast we were away for a hunt. About twelve o'clock a cry of "deer! deer!" came from our youngest, and away we ran, soon to see our guide with a nice deer in his canoe.

But where was L.? There was question after question till all had arrived. Soon the deer was skinned, dressed, and ready for eating; and that the venison was enjoyed was proved by the quantity that disappeared with coffee accompaniment. Thursday L. and Worster, the hunter, went to Oriole Lake for fly-fishing. We passed our time on the beautiful lake, quietly trolling for fish. L. came back bringing with him a string of speckled beauties, which Gabriel soon brought us for our supper; they were almost too good to eat. On Friday Worster and L. started for another deer hunt; and about two hours after, to our great surprise, an- 
FISH : THEIR HABITS AND HAUNTS. 95 other cry of "deer! deer!" came from the lake. N. soon came for us ladies, and we were glad to go into the canoe for a deer chase in the lake. Our only thought was, "if L. were only here." Our guide, who was always willing to please us, left us with the beautiful deer, paddled ashore, and then ran hatless to the other lake, a mile or more distant. He succeeded in finding L., who ran with his gun over rocks and rills. How glad we were to see him appear! He was soon paddled near us, when with one shot our deer was killed. It was an exciting day, and something was seen we had never expected. to see.

To-day two persons from town appeared, also three gentlemen who were camping at the foot of the lake. We had a pleasant call, and they were much pleased with our place and quarters. Mr. W. passed himself off as Mr. C., much, to our amusement later.

The next day we sent to Waite for salt 
96 FISH : THEIR HABITS AND HAUNTS.

to cure skins and for letters, and we had news from home. Saturday we took guides and went to the old camp, where we spent an hour looking at the log-camp and surroundings. The weather was delightful. Soon we left for home and dinner. After reading and writing, J., L., and I started for a walk through the woods back of the camp. Here an owl attracted our attention. $\mathrm{He}$ was soon brought down from his leafy perch, and carried home as a trophy. That night we had our great open-air fire lighted in the open tent; and a fine sight it was! Here, seated on the hemlock boughs, we enjoyed a supper not soon to be forgotten. Our guides served us some nice fried whitefish just from the water, and hot tea. As we had never tasted the fish before, and they are delightfully fine, the enthusiasm of some members of our party could hardly be described. We sat fully enjoying everything without regard to time, but at last finding 
that the small hours were approaching; we reluctantly retired to dream of fish, fires, and Indians.

On Monday the wind blew great gales, but we explored the woods by the camp, and found it a delightful place. There were troutbrooks in abundance, filled with the speckled beauties. Here we strolled till Gabriel's trumpet-like voice resounded through the stillness. We had dinner, which always brought together a merry party; and what a cook! The ladies of the party had had many fears of our guides, but their fear soon became warm friendship. Gabriel Tomah and Tomah Joe are some of the best guides I have ever had. The former is the Grand Sachem of the Passamaquoddy tribe of Indians; and Joe, who had represented his people in the Augusta Legislature, was a smart, intelligent man, ever ready and willing to do all in his power for our comfort; while his assistant, Nouell, was indefatigable 
98 FISH: THEIR HABITS AND HACXTS.

in getting the "old woman wood" for our ladies, much to their amusement. The home of the guides is Lewy's Island, where their occupation is canoe-building and basket-making. Joe is an artist, as the pictures of our, party drawn on birch-bark and presented to the ladies on our departure can testify.

On Monday our guides proposed a trip to Bear Mountain, and we assented. As we looked across the lake at the rocky sides rising so abruptly, Joe said no white woman had ever been up there. Taking a guide in each canoe, we soon were paddled across the lake. The canoes were drawn up on the bank, and we began the climb, and steep and straight the precipice proved to be; but with two hours of hard work we reached the summit, and were repaid a hundred times for the labor. Such an extended view! A tree that obstructed a fine view of Grand Lake was soon felled by Joe, who was ever 
FISH : THEIR HABITS AND HAUNTS. 99 active. We remained, - never tired of the beautiful scenery, varied by lakes, mountain, and distant villages, - till word came that it was time to start back; but we did not start till Joe, who had found a piece of burnt wood, cut a slab trom a huge tree, and left our pictures drawn upon it. Then, "Goodby, Bear Mountain, - shall we ever ascend your steep sides again?" With a merry cheer we took our downward way.

On Tuesday it was delightful weather. We had a fine deer chase of two hours on the lake. One of the ladies lost her hat, but that was nothing. We killed our deer, a: fine one, weighing about three hundred and fifty pounds. The guides soon got him ashore, and dressed and skinned. Then the skins were to be dried and stretched, which process much interested the ladies, who had each the promise of a skin for her home. We need not tell of the delicious venison, cooked in so many ways. Gabriel excelled 
IOO FISH: THEIR HABITS AND HAUNTS.

in his venison stews, and the quantity that disappeared before our keen appetites is almost beyond belief; those of my friends who have spent any time in the woods need not be told of this.

Wednesday we all went round the lakes, each in his own canoe. We broke the stillness by shouting to each other to wake the echo, and a wonderful one it was. Echo Lake in the White Mountains has not so fine an echo. We spent our evening in the light of a full harvest moon. J. would call the echo, while the rest of us would drift lazily with the wind and imagine ourselves in Venice. What moonlight! J. was never tired of hearing the Indians sing in their language, and of listening to the echo. So passed our time, with no care or thought of the morrow. We also stopped for a short time at the deserted loggers' camp, when, with our camera, we took some fine pictures of place and friends. As for our 
FISH : THEIR HABITS AND HAUNTS. IOI

Indians, they were always ready to sit for their pictures at any time. On our way home we met our friend $\mathrm{C}$., with his guide, and it was very pleasant to exchange greeting with one from the outside world, although these same friends tried to escape us in breaking camp. And then Friday, our last day! How short the time had seemed; was it possible that three weeks had passed? But all pleasant things must end, and at length we broke camp, loading the three canoes, which were lashed abreast, and filled till they sank to their edges; took the last picture, - that of the departure; bade goodby to the woods, cove, and inlet, made one last visit to the mink-trap and little cove, and were gone. Shall we ever see old Musquah again? We say, "Oh, yes," and look not behind us.

\section{TRAPS.}

For the benefit of those projecting camping parties are appended the following lists 
IO2 FISH : THEIR HABITS AND HAUNTS.

of articles found convenient on excursions

I have made :-

TRIP FOR TWO PERSONS.

6 cans fishballs.

4 " tongue.

I box sait.

Io lbs. sugar.

2 "soap.

2 (rice.

26 raisins.

6 " cheese.

4 cans cocoa.

I lb. tobacco (for guides).

$\frac{1}{4}$ " pepper.

6 cans milk.

2 lbs. coffee.

2 " best English breakfast tea.

4 cans corned beef.

10 " beans.

6 lbs. buckwheat.

Io " Hecker's flour.

I large ham.

8 lbs. breakfast ham.

25 " crackers.

5 " butter.

3 doz. lemons.

4 boxes sardines.

12 doz. eggs. $\frac{1}{2}$ bushel potatoes.

Apples.

Liquors (for sickness).

Extract ginger.

CLOTHING NEEDED FOR THE TRIP.

Coat.

Rubber coat.

Pants.

Short pants.

Cardigan shirt.

Undershirt.

Woolen shirt.

Three pairs socks.

Tie.

Hat.

Slippers.

Handkerchiefs.

Towels.

Dish towels.

Needles and thread.

6 bags (for provisions).

Oiled leggings.

Moccasins.

Knickerbockers. 
FISH : THEIR HABITS AND HAUNTS. IO3

TRIP, I882, FOR THREE PERSONS FOR THREE WEEKS.

3 guides.

I 8 cans cow milk.

2 cooked hams, very nice.

4 boxes potted tongue.

6 cans peaches.

6 " tomatoes.

6 green corn.

Olives, pickles.

6 corned beef.

$\frac{1}{2}$ doz. lamb tongue.

3 Ibs. sausage meat.

, 2 plum puddings.

2 cans clam chowder.

6 " baked beans.

2 " condensed coffee.

30 Ibs. hard-bread.
6 boxes sardines.

$\frac{1}{4}$ lb. pepper.

Box salt.

2 lbs. soap.

20 lbs. sugar.

Royal yeast powder.

6 lbs. coffee ; 4 lbs. tea.

25 " Hecker's flour.

2 new háms.

3 tongues.

Io lbs. of pork.

Io "lard.

3 doz. lemons, very essential.

Io lbs. butter; 6 dozen eggs.

EQUIPMENTS FOR TRIP TO MOOSEHEAD LAKE.

Tent large enough for six people, folded in canvas bag.

Two blankets for each person.

Thick laced gaiter boots.

Slippers for cainp; sleeping hat.

Rubber pillow ; rubber bag; rubber blankets.

Thick clothes; and some thin clothes.

Landing-net made of oiled linen line, with large meshes; tin box, with lock, for eels; two click reels, and braided oiled-silk line enough to go on both reels 
IO4 FISH : THEIR HABITS AND HAUNTS.

Fly-book, without flannel leaves, with pair scissors inside.

One fly-rod weighing about eleven ounces.

One fly-rod weighing about sixteen ounces.

Spare tips; spare rings; tools for mending rods, including small file, wax, etc. ; pincers ; black silk.

Flies - dozen and a half each, of black nackle, red tail, scarlet ibis, with some white about them; blue jay, imported feathers; golden pheasant, tinsel body ; brown nackle.

If possible have half the above flies made large, the size of salmon files. 
IN MEMORIAM. 



\section{IN MEMORIAM.}

Ir is with deep sorrow that I record the death of Mr. Lorenzo Prouty, for many years at the head of the fishing-tackle department of the house of Bradford \& Anthony, Boston. For nearly a score of years had I known him, and never in any other character than as a courteous gentleman, a devoted angler, and an honest man.

Amid the din of the busy town, at his duty, it was my pleasant privilege to "drop in" for a few moments and exchange words with him about babbling brooks and secluded lakes, and the fish thereof; and to see him no longer as of yore is another bitterness added to life's fast increasing tally. His loss will be deeply feit by all fishermen who were wont to replenish their kit at his deft hands, 
and his sudden and sad "taking off" will be deplored by all who knew him.

Here and now I am constrained to pay a fond tribute of praise to an honest angler, whose genial and kind face has been lately hidden by the cerecloth of death, and whose form has been lain away in the dust to await the general resurrection at the last day. How often in our piscatorial chat have I seen his eye gleam with pleasure and his face alit with the love of the craft, of which he was so thoroughly the master.

His was a type - and a right noble one of an honest angler's life and love ; and those who knew and loved him the best miss him and mourn him the most sincerely. Quiet, gentle, unobtrusive, like many a pure stream he was wont to love and cast his fly upon, he passed from our sight so suddenly that his loss cannot be fully realized. "Lord (to us), keep his memory green, and may light perpetual shine upon him!" 
The memory of such is precious. Requiescat in pace! In this prayer I am sure all brethren of the gentle art will join me. Forest and Stream.

To every angler throughout New England, and even beyond its borders, the tidings of the sudden death of Lorenzo Prouty will come with a personal sense of bereavement. His death is a loss to the constantly-increasing ranks of gentlemen sportsmen. Next to his own kith and kin, the brethren of the "gentle art" will most seriously mourn his entrance into rest, not grudgingly, for "after life's fitful fever he sleeps well," but with an individual and selfish regret that his intercourse with them on earth is ended. In domestic, social, and business life he was a kindly, courteous, and honest man; and the rising of each day's sun shone on some new friend, won to his side by the innate kindliness of his genial nature. $\mathrm{He}$ was a man 
and an angler after our beloved master Walton's own heart; and he truly possessed and practised many of the characteristics and virtues of "good old Izaak Walton" of blessed memory to all who "be quiet and go a-angling."

Memory "harks back" through nearly a score of years of acquaintance with this accomplished fisherman, and always with pleasure; and 'tis hard to realize that his deft hand will no more cast the fly as an adept, or his sound advice be given to the novice in the craft which he so well loved and honored! He will be missed in many a pleasant camp, now sacred to his memory; and with trembling voice and uplifted hat will his name be spoken by river and mere, on moor and mountain.

Peace to thee, friend and angler! Thy memorials are in many hearts, and in the fly-books and "kits" of thy angling friends will be recalled the pleasant voice and smile. - O. W. R., in Boston Transcritit, Fan. 2, 1883 . 
An Angler's Rest.

IN MEMORIAM LORENZO PROUTY.

"After Life's fitful fezier he sleeps well."

SwEET spring has come to the beck-side, And to the mountain mere;

Scattered her favors far and wide, Attuned her voices clear;

But a void in all there seems :

As we wander, rod in hand, We miss the ever-kindly gleams Of his eye and grasp of hand.

A "quiet eye" and true he bore, Fair mirror of his heart;

He loved the dappled meadows more By far, than busy mart ;

And mountain pine and hemlock seem

To sigh, in sad refrain,

As they shade the babbling brooklet's gleam,

"He ne'er will come again!"

The May-fly (o'er the silent "deep,"

Whose semblance oft he cast)

Now tempts the lusty trout to leap

Till its brief life is past; 
The gloaming comes, the camp-fire glows,

With ever-welcome grace,

But, from his new and long repose,

He comes not to his place.

No huntsman's horn, no angler's glee,

Can rouse him from his sleep;

But, in our stricken hearts, may we

His "memory green" aye keep !

Afield or by the stream, he left

No "blaze" of shame or greed;

A sportsman undefiled and deft, -

Our craft's Bayard, indeed !

Time's silent stream on, ever on,

Unheeded by him flows;

It bears us to the port he's won,

Through "seasons" free and "close."

We sign the cross upon his grave,

With rod of true incline,

And, as we fish, on him we crave

Perpetual light may shine.

- O. W. R., in Forest and Stream.

It will be sad news, indeed, to the many near and distant friends of Mr. Prouty, at the 
beginning of the new year, to hear of his decease, and sadder still when they learn that the summons came suddenly, just as he was about to embark in business with a friend of years' standing, and with every prospect of success.

Mr. Prouty had been in the employ of Messrs: Bradford \& Anthony, of this city, for twenty-seven years, and was known far and near by all lovers of the rod and gun ds a gentleman particularly adapted for the position which he occupied at the head of the fishing-tackle department of the above house. He was a true sportsman, a keen lover of nature, a companionable friend, a tehder husband, a devoted father, and a man of the strictest integrity.

It was expected, by his intimate friends, at least, that he would have an interest in the business of Messrs. Bradford \& Anthony after their retirement, he having done so 
much to build up that particular branch of their business, for which he was by nature and education so well qualified; but it was not to be, and during December he left them to engage in a similar business with his friend Mr. George B. Appleton, also long and favorably known as being connected with the same house.

No words of sympathy, however tenderly expressed; no words which we can utter, no tears which we may shed, can restore to its completeness that once so happy, now so desolate home; but to her who waits in sadness may come to soften the asperity of the blow the sad yet feeble consolation that the departed loved one will be mourned in many a household throughout our land. Truly, -

"God moves in a mysterious way, His wonders to perform."

- G. W. S., in Forest and Stream, Fan., 1883. 
One of our most beloved members of society, a true-hearted fellow-man, a lover of all nature as the great Designer made it - the primeval forest and all that was placed therein, and God's beautiful lakes and streams, and their inhabitants, - in fact and reality the type of a good man, and a true sportsman, was Lorenzo Prouty. Few men in the New England States were more generally known and universally loved. M., in Forest and Stream. 



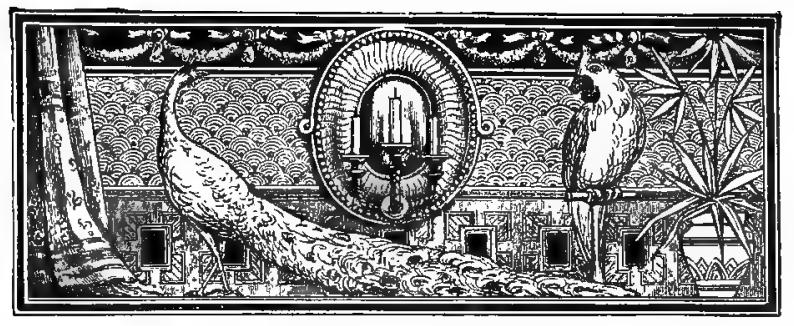

\section{A LIST OF BOOKS}

\section{PUBLISHED BY

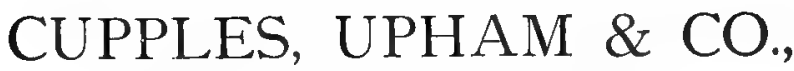

\section{WASHINGTON STREET, BOSTON.}

ANDREW. The Errors of Prohibition. An Argument on the Matter of License and Prohibition. By the late JOHN A. ANDREw, Guvernor of Massaclusetts. Paper. 8vo. 50 cents. Terth thousand.

ATKINSON. Our National Domain: A Graphical and Statistical Chart. By EDWARD ATKINSON. Printed in colors and enclosed between handsome board covers., so cents.

位 It can be obtained, if desired, mounted on rollers and varnished, suitable for hanging on the wall. Price, $\$ 1.25$.

ATKINSON. What is a Bank? What Service does a Bank Perform? By Edward Atkinson. 8vo. Pamplilet. 25 cents.

ATKINSON, Edward. The Railroads of the United States: their Effects on Farming and Production in that Country and Great Britain. By Edward ATKINson. 8vo. Pampllet, with chart. so cents.

ATKINSON. Comparative Geography: the Area of the Political Divisions of the world shown graphically in colors. BY EDWARD ATKINSON. On roller. For the use of schopls. \$3.00. In preparation.

ATWATER'S History of the Colony of New Haven. 8vo. $6 \times 1 \mathrm{pp} . \$ 4.00$.

BAILEY. The Book of Ensilage; or, the New Dispensation for Farmers. By John M. Balley. 8vo. Cloth. 202 pages. Portrait and illustrations. \$1.00. Paper, 5o cents.

** A work of incalculable importance to the farmer, treating the new system of feeding cattle.

BATES. "Risk," and other Poems. By Charlotte Frske BATES, enitor of the "Longfellow Birthday Book." s6mo. Red edges. \$1.00. Little Classic style.

**" "Crystallizations of subtle thoughts and fancies." - Fohn G. Whittier.

BIGELOW. Litholapaxy or Rapid Lithotrity with Evacuation. By Henry J, Bigelow, M.D. 8vo. Cloth. Illustrated. \$1.oo.

BOTH. Small-Pox. The Predisposing Conditions, and their Prevention. By Dr. CARL Both. 12mo. Paper. 50 pages. Price, 25 cents. BOTH. Consumption. By Dr. CARL Both. 8vo. Cloth. \$2.00. 
BOWDITCH. Suffolk Surnames. (Surnames of Suffolk County, Massachusetts.) By Nathaniel Ingersol, Bowditch. 8vo. Cloth. 383 pages. \$2.00. Secondedition, enlarged.

BOYCE. The Art of Lettering, and Sign Painter's Marsual. A Complete and Practical Illustration of the Art of Sign-Painting. Oblong 4to. By A. P. Boyce. 36 plain and colored plates. \$3.50. Fourth edilion.

BOYCE. Modern Ornamentor and Interior Decorator. A Complete and Practical Illustration of the Art of Scroll, Arabesque, and Ornamental Painting. By A. P. BoyCE. Oblong 4 to. 22 plain and colored plates. Cloth. \$3.50.

BUTTS. Tinman's Manual, and Builder's and Mechanics' Iandbook, designed for Tinmen, Japanners, Coppersmiths, Engineers, Mechanics, Btilders, Wheelwrights, Smiths, Masons, \&c. Sixth edition. r2mo. Cloth. 120 pages. \$1.20.

BUTTS. The New Business-Man's Assistant, and Ready Reckoner, for the use of the Merchant, Mechanic, and Farmer, consisting of Legal Forms and Instructions indispensable in Business Transactions, and a great variety of Useful Tables. By I. R. BuTTs. I vol. 12mo. 132 pages.

$5^{\circ}$ * cents.
*. It would be difficult to find a more comprehensive manual for every-day use, than this valuable Assistant.

CAPE COD FOLKS. A Novel. Illustrated. Immo. Cloth. \$1.50. ** A powerfully written story, depicting the characteristics of a class conspicuous the world over for keenness, originality, and humor.

CHANDLER. A Bicycle Tour in England. By A. D. CHANDLER. I vol. Small 4 to. In sreparation.

* * Full of views of out-of-the-way nooks, castles, country seats, unsurpassed for clearness and beauty.

CUPPLES. The Deserted Ship: a Story of the Atlantic. By Geo. Cupples, author of "The Green Hand." Illustrated. $12 \mathrm{mo}$. \$1.50. Fourth edition.

CUPPLES. Driven to Sea; or, the Adventures of Norrie Setor. By Mrs. George Cupples. Illustrated. Izmo. Clotlk. \$1.50. Second thousand.

CUPPLES. Singular Creatures; or, Stories from a Scotch Parish. By Mrs. Grorge Cupples. Illustrated. 12mo. Cloth. \$1.50. Second thousand.

Whipple.

DERBY. Anthracite and Health. By Geo. Derby, M.D. Harv. t2mo. 76 pages. Cloth, limp. 50 cents. Second edition, enlarged.

DES CARS. A Treatise on Pruning of Fruit and Ornamental Trees. Translated by C. S. SARGENT (Harvard). Engravings. I2mo. Cloth 75 cents.

DIRECTORY OF BOSTON CHARITABLE INSTITUTIONS. I2mo. Cloth. 182 pages. 50 cents, net.

DRAKE. Memorials of the Society of the Cincinnati of Massachusetts. By F. S. Drake. Royal 8vo. Cloth. $5^{8} 4$ pages. Many steel engravings. \$ 13.00 ret.

ELLIS. The Evacuation of Boston, with a Chronicle of the Siege. By George E. ElLis, LL.D., author of "The Life of Count Rumiord," \&c., \&c. With steel engravings, full-page heliotype fac-similes, maps, \&c. I vol., imperial $8 \mathrm{vo}$. \$3.00. remain.

** A monument of historical research and industry. Only a few copies now

FIRST HELP IN ACCIDENTS AND SICKNESS. A

Guide in the absence or before the arrival of Medical Assistance. Illustrated with numerous cuts. 12 mo. Cloth. 265 pages. \$1.50.

"A very useful book, devoid of the quackery which characterizes so many of the

health manuals." $-A m$ Med. $O b$. 


\section{FIRST LESSONS IN THE ARTICLES OF OUR FAITH,}

And Questions upon Our Church Doctrines, and upon the Life of Christ, with their Answers from Scripture. For young learners. With introduction by Rev. Phillips BROoKS, D.D. 2 vols. Boards. 70 cents.

FISHER. Plain Talk About Insanity. Its Causes, Forms, Symptoms, and Treatment of Mental Diseases. With Remarks on Hospitals, Asylums, and the Medico-Legal Aspect of Insanity. By T. W. F ISHER, M.D., late of the Boston Hospital for the Insane. 8vo. Cloth. \$ 50 .

FOLSOM. Disease of the Mind. Notes on the Early Management, European and American Progress, Modern Methods, \&c., in the T'reatment of Insanity. By Charles F. Folsom, M.D., Secretary of the Massachusetts Board of Health. Illustrated. 8vo. Cloth. $\$ 1.25$.

FOLSOM. The Four Gospels, from the Text of Tischendorf. By N. S. Folsom. 12mo. Cloth. 486 pages. \$2.50. Third edition.

GODDARD. Newspapers and Newspaper Writers in New England, $77^{8} 7$-18rg. By D. A. GODDARD, editor of Boston Daily Advertiser. 8 vo. Pamphlet. 5o cents.

GRANT. The Confessions of a Frivolous Girl. A Story of Fashionable Life. Edited by RoberT Grant, author "The Little Tin Gods-onWheels." With vignette illustrations by L. S. Ipsen. I6mo. Cloth, extra, \$1.25. Paper, 75 cents. Tenth thousand.

**" A charming novel, abounding in clever comment, good-natured sarcasm, and witty reflection." - Saturday Evening Gazette.

GREEN. Early Records of Groton, Massachusetts. By Samuel A. Green. 8vo. Cloth. 20r pages. \$2.00.

GREENE. The Blazing Star: with an Appendix treating of the Jewwish Kabbala. Also a 'Tract on the Philosophy of Mr. Herbert Spencer, and one on New England Transcendentalism. By W. B. GreENE. 12mo. Cloth. I 80 pages. $\$ 1.25$.

GUARD (DE LA). The Simple Cobler of Aggavvam in America. By Theodore de la Guard. 16 mo. Pamphlet. 50 cents. *** A fac-simile reprint of the London edition of 1647 .

HALL. Masonic Prayers. 4to. Large type. Limp. Cloth. \$I.25.

HALL. Master Key to the Treasures of the Royal Arch. A complete guide to the Degrees of Mark Master, Past Master, M. G. Master, and Royal Arch. Approved and adopted throughout the United States. By JoHN $\mathrm{K}$ HaLL. Morocco, tuck. 75 cents.

HALL. Master Workman of the Entered Apprentice FellowCraft, and Master Mason's Degrees. By JoHN K. HALL, P. H. P. of St. Paul's R. A. Chapter, Boston, Mass., and P. D. Gr. H. P. of the Grand Chap. of Mass. Morocco, tuck. 75 cents.

HASKINS. Selections from the Scriptures. For Families and Schools. By Rev. D. G. HASkins. I vol. 24 mo. 402 pages. \$1.50.

HOWE. Science of Language; or Seven-Hour System of Grammar. By Professor D. P. Howe. Pamphlet. 5ó cents. Thirtieth thousand.

HUBBARD. Summer Vacations at Moosehead Lake and Vicinity. A Practical Guide-book, by L. L. HUBBARD. With maps and twenty beautiful photograph illustrations done in heliotype. $16 \mathrm{mo}$. Cloth. II4 pages. \$1.50. Paper covers. so cents.

JEFFRIES. Diseases of the Skin. The Recent Advances in their Pathology and Treatment, being the Boylston Prize Essay for 1871 . By B. JoY JEFFRIES, A.M., M.D. 8vo. Cloth. \$1.00.

JEFFRIES. The Animal and Vegetable Parasites of the Human Skin and Hair, and False Parasites of the Human Body. By B. Joy Jefrries, A.M., M.D. I2mo. Cloth. \$1.00. 
LNG. The War-Ships and Navies of the World. Containing a complete and concise description of the Construction, Motive Power, and Armaments of Modern War-Ships of all the Navies of the World, Naval Artillery, Mariue Engines, Boilers, Torpedoes, and Torpedo-Boats. By Clijef Engineer J. W. KiNG, U. S. Navy, author of "King's Notes on the Steam-Engine." I vol. $8 \mathrm{vo} .500$ pages. 64 full-page illustrations. $\$ 7.00$

*** "The ablest, most interesting, and most complete work on the subject in the English language." $-E$ dinburgh Review.

KING. Handbook of Boston. By Moses Krng. Profusely illustrated. $12 \mathrm{mo}, 296$ pages. Paper, 60 cents. Cloth, \$ 1.00.

KING. Harvard and its Surroundings. Copiously illustrated with heliotypes, wood engravings, and etchings. Small 4 to. \$ 8 r.50. Paper, \$1.oo.

KNAPP. My Work and Ministry, with Six Essays. By Rev. W. H. KNAPP. 86 omo. 327 pages \$8.5o. Third edition.

LAIGHTON. Poems by ALBERT LAIGHTON. Frontispiece. 16 mo. Cloth, gilt. 125 pages. $\$$ r.oo.

** 'l'he author is a native of Portsinouth, N. H., and this litule volume is of sipecial interest to natives of that ancient city.

LEIGH. Modern Cotton Spinning. By EVAN LEIGH, C. E. 2 vols. Quarto. Profusely illustrated. Price \$30.00. Second and enlarged edition.

"LET NOT YOUR HEART BE TROUBLED." Square 12 mo. Leaflet, tied. $4^{8}$ pages. Printed in two colors. Illuminated cover. 75 cents. Fourth thousand.

LITTLE. Early New England Interiors. By Arthur Little. A Volume of Sketches in old New-England places. Thick oblong quarto.

\$5.".0. To those far distant, unfamiliar with the nooks and corners of New England, and prone to consider the work of Puritanical colonists, noticeable only for its lack of taste, and conspicuous for green blinds and white painted walls, this work will be a revelation." - Boston Daily A dvertiser.

LOVING WORDS FOR LONELY HOURS. Oblong, leaflet, tied. 22 pages. Printed in two colors. 50 cents. Sixth thonsand.

LOVING WORDS FOR LONELY HOURS. Second series. 22 pages. 50 cents. Second thonisand.

LÜCKE. Surgical Diagnosis of Tumors. By A. Lücke (Strasburg). Translated by A. T. СABot, M.D. J6mo- Pamphlet. 25 cents.

MALLOCK. Every Man His Own Poet; or, The Inspired Singer's Recipe Book. Iomo. Paper. Price, 25 cents. Fifth thousand. ** A most enjoyable piece of satire, witty, clever, and refined. In society its success, here and abroad, has been immense.

MITCHELL. A Manual for the Use of Clergymen and Others Preparing Classes for Confirmation. By Rev. W. MitchelL Pamphlet, ro cents.

MORRIS. ' The Autobiography of Commodore Charles Morris. With heliotype portrait after ARY SCHEFFER, I vol, 8vo. 11 pages. Si.co.

* * A valuable addition to the literature of American history and biography from the pen of one who, in the words of Admiral Farragut, was "America's grandest seaman."

MORRISON. History of Morison and Morrison Families. 468 pages. 8vo. \$3.00.

NANTUCKET RECEIPTS. Collected chiefly from Nantucket sources r6mo. Pamphlet. 40 pages. 25 cents.

NEWTON. Essays of To-Day. Religious and Theological. By Rev. WM, W. Newton, Rector of St. Paul's Church, Boston. 12mo. Cloth 253 pages. \$2,00. 
PARKER. The Battle of Mobile Bay and the Capture of Forts Powell, Gaines, and Morgan. By Commodore FOXHALL A. PARKER. 8vo. Cloth, elegant. 136 pages. Portrait and two colored charts. \$2.50.

PEABODY. Æsthetic Papers. Edited by Elizabeth P. PEABody. $I$ vol. 8vo. Pamphlet. 248 pages. \$2.00. Boston, 1849 .

* * A rare pamphlet, of which but a few copies remain for sale. It contains early papers by Emerson, HAwTIIORne, PARKe Godwin, Thoreau, and othets.

PREBLE. A History of the Flag of the United States of America, and of the Naval and Yacht Club Signals, Seals, and Arms, and principal National Songs. With a Chronicle of the Symbols, Standards, Banners, and Flags of Ancient and Modern Nations. By Rear Admiral GeORGE HENRY Preble, U. S. Navy. I vol. 8vo. Price, \$7.00.

*** A masterly and encyclopedic production, absolutely without a rival, conveying to the general reader, is a manner eminently readable, a fund of information on the naval and military history of the country. It is profusely illustrated.

ROLLO'S JOURNEY TO CAMBRIDGE. A Tale of the Adventures of the Historic Holiday Family at Harvard under the new régime. With twenty-six illustrations, full-page frontispiece, and an illuminated cover of striking gorgeousness, by 'FrANCIS G. A TTwOOD. I vol. Imp. 8vo. Limp. London toy book style. Price, 50 cents. Third and enlarged edition.

*** "All will certainly relish the delicious satire in both text and illustrations." .Boston Travelles.

*** "A brilliant and witty piece of fun."-Chicago Tribune.

RUंDINGER. Atlas of the Ossean Anatomy of the Human Ear. Comprising a portion of the Atlas of the Human Ear. By N. Rüdngre. Translated and edited, with notes and an additional plate, by CLARENCE J. BLAKE, M.D. 9 plates. 4to. Cloth, extra. 3.50 .

*** The plates are the same as in the German edition, and were imported specially for this edition.

SMITH. Myths and Idyls of the Present; or, Stories and Dialogues in Prose and Verse, for Young and Old Hearts. By ElizA Winchell Smith. 278 pages. Square I2mo. Cloth. \$1.50.

* * Deserving of being widely known and extensively circulated amongst those who have liealthy appetites for books free from sentimentalism, goodiness, and slang.

SPALDING. The Ordinance of Confirmation: its History and Significance. By the Rev. J. F. Spalding. 8vo, Paper. $2 x$ pages. I5 cents.

SPRAGUE. Poetical and Prose Writings of Charles Sprague. New edition, with steel portrait and biographical sketch. ramo. Cloth. 207 pages. \$1.50.

STEVENS. Fly Fishing in Maine Lakes; or, Camp Life in the Wilderness. By C. W. STrVens. With 38 vignette illustrations, and colored frontispiece, showing the best killing flies in vogue. Square $12 \mathrm{mo}$. Cloth. $\$ 1.25$.

*** A bright and attractive book for every angler and sportsman, full of breezy sketches replete with incidents. It is as practical as it is humorous.

STEVENS. On Ensilage of Green Forage Crops in Silos. Experience with Ensilage at Echo Dale Farm. Also the Practical Experience of Twenty-five Practical Farmers with Ensilage and Silos. By H. R. Stevens. I vol. 8vo. Cloth. 5o cents.

STEVENS. Revelations of a Boston Physician. By Charles Wistar Stevens, M.D. rmo. Cloth. 252 pages. \$1.00.

** A work that does for Boston what Warren in his "Diary of a Physician" did for London.

STONE. Domesticated Trout. How to Breed and Grow them. By Livingston Stone. rzmo, 367 pages. \$2.00. Third edition. Revised and enlarged.

STURTEVANT. The Dairy Cow. A Monograph on the Ayrshire Breed of Cattle. With an Appendix on Ayrshire, Jersey, and Dutch Milks; their Formation and Peculiarities. By E. LEwIS, M.D., and JAmzs N. STURTeVANT. $12 \mathrm{mo}, 252$ pages, 1llustrated. \$2.00. 
TIE GAS CONSUMER'S GUIDE. Illustrated, I2mo. Cloth, $\therefore$ oo. Paper, 75 cents.

TOWER. Modern American Bridge Building. Illustrated. I vol. 8vo. Cloth. \$2.00.

UNDERWOOD. History of the 33d Massachusetts Regiment. By Gen. A. B. UNDERWOOD. 8vo. 340 pages. \$3.00.

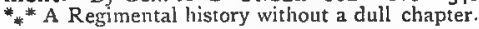

VILLE. High Farming without Manure. Six Lectures on Agriculture, By George VILle. Puiblished under the direction of the Massachusetts Society for the Promotion of Agriculture. $16 \mathrm{mo}$. 108 pages. Price, 25 cents, * A wonderfully cheap edition of a famous book.

WARE. Hints to Young Men on the True Relations of the Sexes. By JoHN WARE, M.D. I6mo. Cloth, limp. 50 cents, Twentieth thousand.

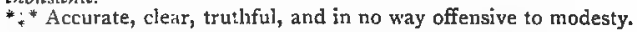

WARREN. Surgical Observations with Cases and Operations. By T. MASON WARREN, M.D. With fine, colored illustrations and many wood eneravings. 8vo. Cloth. 630 pages. \$3.50.

** l'he last published work of this eminent surgeon.

WATson. A Course of Descriptive Geometry. For the use of Colleges and Scientific Schools. With an Appendix containing Stereoscopic Views of the Solutions in Space of the Principal Problems. By William Watson, Ph.D. Plates. Quarto. Cloth. \$3.00.

WATSON. European System of Instruction: Studio and A telier. With the most approved Models and Appliances recently selected from the 'Technical Schools of France, Germany, and Austra. By Willtam Watson, Ph.D. 8vo, Boards. 5o cents.

WHEELWRIGHT. A New "Chance Acquaintance." A Trifle served up on Twelve Plates, by J. T. WheELWRIGht. Illustrated by F. G. ATTWOod, 12 mo. Paper. 25 cents.

*** A Boston jer d'esprit in verse. Very clever and witty.

WHITEFIELD. The Homes of our Forefathers. Being a collection of the oldest and the most interesting buildings in Massachusetta. From original drawings in colors by E. WhITEFIELD. With Historical Memuranda. I vol., oblong quarto, cloth, neat, gilt edges, bevelled, \$5.0o.

*.*A work that gives, with the faithfulness of a photograph, the curious, pictur-

esque and always interesting relics of colonial days that still remain to Massachusetts.

WHITNEY - CLARKE. A Compendium of the most important Drugs with their Doses, according to the Meti ic System. By W. F. WHITNEY, M.D. and F. H. Clarke. 32mo. 40 pages. 25 cents. Specially made to fit the Vest Pocket.

WINES. The State of Prisons and of Child-Saving Institutions in the Civilized World. By E. C. Wines, D.D., LL.D. I vol. Large 8 vo. 719 pages. $\$ 5.00$.

*** A vast repository of facts, and the most extensive work issued in any language, on matters relating to prison discipline and penal justice.

WORCESTER. History of Hollis, New Hampshire. By

S. T. Worcester. Maps and engravings. 8vo. 394 pages. \$2.50.

For sale by all booksellers, or mailed, postage paid, on receipt of price.

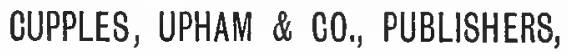

BOSTON. 


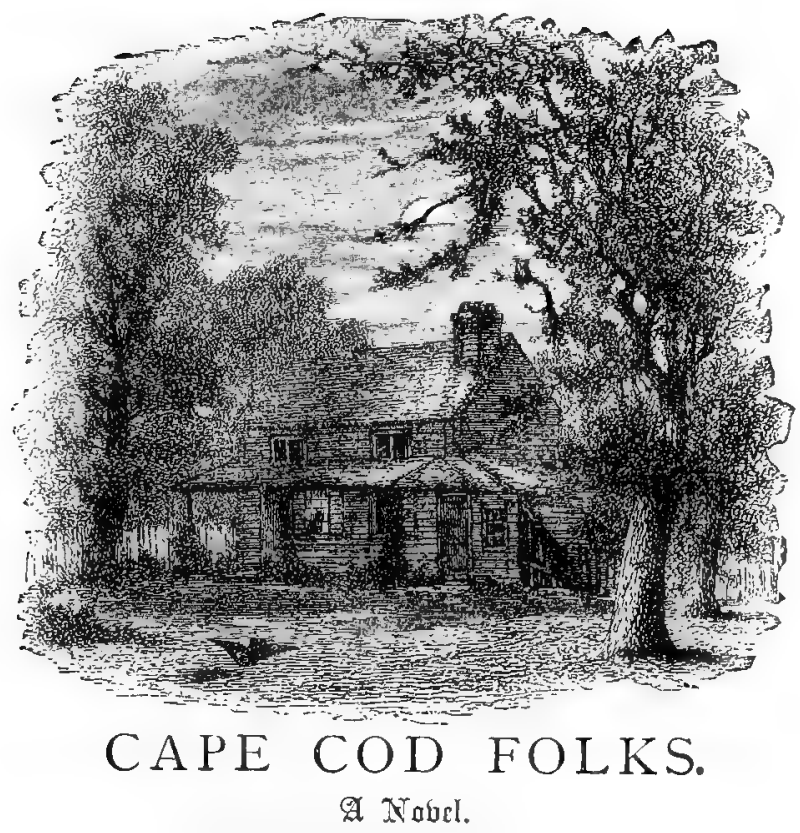

BY SALLY PRATT MCLEAN.

I Volume. 12mo. $\quad$ Price, \$1.50. 327 Pages. Cloth, gilt.

"Those who take up this volume expecting a commonplace story with which to while away a few hours, will find themselves most agreeably surprised. It is full, from beyinning to end, of the most delicinus humor, while through the whole runs a vein of pathos that touches and thrills to tears in the midst of laughter. Onc feels that the quaint characters described lhere have their counterparts, that it is real life upon the bleak Cape Cod of which we are reading. The warmest love flows out to Grandpa and Grandma Spicer, whose horizon is bounded by the ocean upon which Grandpa has spent so inany years of his life, and who are both so kindly natured and full to the brim of gondness. Ienny Cradlebow, the unlettered young $A$ pnllo, cliallenges our sympathy from the first to the last, when he loses his life in trying to save that of his would be rival." - Toledo Blade.

"There is real power in her characterization. Real elnquence in lier account of the uncultivated singing. . . Real pathos in the vague religious opinions and intense religious sentiment of these simple, brave people." Boston Adzertiser.

"Her description of the provincial traits of this most provincial of all the outlying New England settlements, are admirable bits of genre workmanship." - Harper's Magazine.

\section{CUPPLES, UPHAM \& CO., PUBLISHERS,}




\title{
CAPE COD FOLKS.
}

\author{
A XYouel.
}

\author{
BY SALLY PRATT MCLEAN.
}

I Volume. I2mo. 327 Pages. Cloth, gilt. Price, \$1.50.

CUPPles, UPHAM \& CO., Publishers,

BOSTON.

\section{OPINIONS OF THE PRESS ON THE WRITINGS OF THE NEW AMERICAN HUMORIST.}

"So natural and true to life are some of the characters, lncalities, and incidents depicted in the book, that the observing reader finds it difficult to persuade himself that he is not reading the autobiography of a vivacious school-teacher in real life. The scenes and incidents of the novel are by no means commonplace, however, and there is just enough of the improbable and impossible in the story to give it piquancy and thorough zest." Boston Post.

"We rather doubt the justice or policy of ranking the work as a novel, for it is really a triumph of character sketching, with nolistic developments." - Boston Sinday Times.

" Every chapter is fresh and sparkling with life and humor, and we cannot help but eulogize the author for her inasterly hand and genius of storytelling." $-N . Y$. Star.

"Those who take up this volume expecting a commonplace story with which to while away a few hours, will find themselves most agreeably surprised. It is full, from beginning to end, of the most delicious humor, while through the whole runs a vein of pathos that touches and thrills to tears in the midst of laughter. One feels that the quaint characters described here have their counterparts, that it is real life upon the bleak Cape Cod of which we are reading. The warmest love flows out to Grandpa and Grandma Spicer, whose horizon is bounded by the ocean upon which 
Grandpa has spent so many years of his life, and who are both so kindly natured and full to the brim of goodness. Benny Cradlebow, the unlettered young Apollo, challenges our sympathy from the first to the last, when he loses his life in trying to save that of his would-be rival.

"The plot is nothing, and yet the reader is not aware of its absence. The book is simply a picture of the events in a few months of the life of a young girl who was seized with the idea of doing missionary work, and goes to Cape Cod as a teacher. It is as crisp as the air in that sed-bound place, and as sparkling as its starry skies. Tlyat it is true to nature is cvident from the fact that its publishers have had a libel suit upon their hands on its account. Buy and read it. You cannot fail to be entertained." - Toledo Blade.

"There is real power in her characterization. Real eloquence in her account of the uncultivated singing. - Real pathos in the vague religious opinions and intense religious sentiment of these simple, brave people." Boston Advertiser.

"Her description of the provincial traits of this most provincial of all the nutlying New England settlements, are admirable bits of genpe workminship." - Harper's Magazine.

"It is a rarely powerful and realistic picture of simple life." - Buffalo Express.

"The author has given us a charmingly fresh and thoroughly recognizable portraiture." $-N, Y$. Trazieller.

"It is a phenomenal, work." - Portland Transcript.

"It is an insult to literature for well-read lawyers to treat this capital novel as if it were a mere vulgar libel." - Boston Transcript.

"That book has been the means of shaking literary Boston almost to its very centre."- Quebec Chronicle.

"It is intensely amusing, and portrays vividly and faithfully the daily life of a peculiar people." - Golden Rule.

"It contains more and better character-writing than any book of its kind we have seen for many a day." - Chicago Inter. Ocean.

" There are some delicious bits in 'Cape Cod Folks.' The literary style is excellent, and the book is of a kind to please almost everybody." $-N . Y$. Herald.

"No man reads 'Cape Cod Folks' with more delight than a genuine Cape Codder. As I am one of that ilk, I am, of course, one of her admirers. The bottom fact about her book is that it is true, and paints truth down to its hidden roots, as the wont of genius is. This is the general verdict of those who ought to know. It is an American book, racy of the soil." Correspondence to Lilerary World.

"The touch of a new hand, at once original, intense, and dramatic, with a vein of humor and a power of sarcasm warranting the belief that in this work we have the beginning of a career and of a name." - Boston Herald. 


\section{THE NEW NOVEL, BT THE AUTHOR OF "CAPE COD FOLKS."}

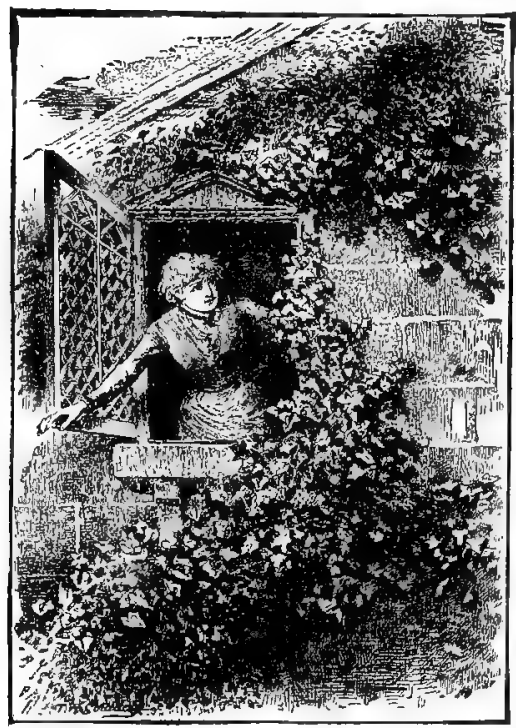

\section{TOWHEAD; the Story of a GirL.}

\section{BY SALLY PRATT MCLEAN, AUThOR OF "CAPE COD FOLKS."}

\section{IVolume. Iamo, cloth. Uniform with "Cape Cod Folks." Price, $\$ 1.50$.}

This is a story altogether American in plot and character. It combines the same spirited and humorous style which characterized "Cape Cod Folks," with that pathetic touch so peculıarly her own, which has made Miss McLean such a phenomenon in the world of letters.

\section{CUPPLES, UPHAM \& CO., PUBLISHERS,} BOSTON. 


\title{
NICHOLS
}

\section{POPULAR SCIENCE NEWS}

AND

\section{BOSTON JOURNAL OF CHEMISTRY.}

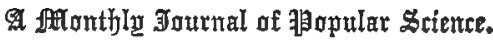

CONDUCTED BY

DR. JAS. R. NICHOLS AND WM. J. ROLFE, A.M.

Established in 186s. Now in its Serventeenth year.

One Dollar per Annum in advance.

The name Popular ScIence Niws has been associated with the Boston Journal of Chemistry, a paper long and favorably lnown in every State of the Union. The design of this most successful and useful journal has been to furnish in compact form, and at a low price, the new facts in science, mechanics, invention, art, agriculture, and medicine, which it is so important should be widely disseminated among all reading people.

Its success is due to the fact that it presents in plain language, which all can understand, scientific discoveries and principles which are useful to every one, no matter what may be their rocation or pursuit in life. It is an indispensable

\section{FAMLY JOURNAL,}

which should be introduced to every fireside in the country.

Dr Nichols has edited this journal for a period of more than a sixth of a century, and every number contains maxy pages of his instructive and pleasant contributions.

Send One Dollar to POPular Sciexce Niws Co., 105 IIjgh Strect, Boston. You will receive it promptly, and not regret that you became its patron. 


\section{THE STORY OF IDA.}

By FRANCESCA.

WITH A FINE PORTRAIT FRONTISPIECE, AND AN INTRODUCTION

BY JOHN RUSKIN, D.C.L.

I vol. I6mo. Gray cloth and gilt. Price, 75 cts.

THIS reprint of a little book which has been very popular in England is meeting with a warm welcome throughout the country. Its popularity is due mainly to the beauty of the story, although attention was called to it, in the first place, by Mr. Ruskin in his lectures at Oxford, and in the preface to the book. The pseudonym, "Francesca," is only a slight change of the Christian name of Miss Frances Alexander, a lady artist of Boston, now living in Florence. The great merit of her paintings won her the friendship of Mr. Ruskin, at whose urgent request "The Story of Ida"-written originally as a private memorial was published. In his preface Mr. Ruskin says:-

"Let it be noted with thankful reverence that this is the story of a Catholic girl, written by a Protestant one, yet the two of them so united in the truth of Christian faith, and in the joy of its love, that they are absolutely unconscious of any difference in the forms or letter of their religion."

"The Story of Ida' is a perfect gen of simple, unadorned narratize, and the volume is a dainty little specimen of the bookmaker's art." - BUFFALO EXPRESS.

"The story is very touching." - Boston AdVERTISER.

"It is tender, lowing, and deeply religious." - WORCESTER SPY.

"This exquisite little story, with its preface by John Ruskin, depends for its interest upon a certain religious simplicity and refinement of thought and manners, which will commend it to those who like the works of Frances Havergal and Hesba Stretton." - Boston Courier.

"The story is beautiful and touching in its simplicity, purity, and pathos, and is absolately true in every particular." - TROY TIMEs.

For sale by all booksellers, or mailed, postage paid, on receipt of the price, by the publishers,

\section{CUPPLES, UPHAM AND COMPANY,}

283 Washington Street, Boston. 


\section{The Deserted Ship; a Story of the Atlantic.}

By George Cupples, author of "The Green Hand." Hand. somely bound in cloth, gilt, extra. I 2 mo. Illustrated. \$r.25.

"In these two absorbing sea stories-" The Deserted Ship," and "Driven to Sea" - the peril and adventure of a sailor's life are graphically described, its amenities and allurements being skillfully offset by pictures of its hardships and exposures, and the virtues of endurance, fortitude, fidelity, and courage are portrayed with rough and ready, and highly attractive effusiveness." -Harper's Magazine.

\section{Fly Fishing in Maine Lakes; or, Camp Life in the Wilderness.}

By Maj. Charles W. Stevens, Commander of the Ancient and Honorable Artillery Company, Boston. With colored frontispiece of the best killing flies, and rubricated title-page. Square I 2 mo. Cloth. 201 pages. \$1.25.

"It is written as naturally and unaffectedly as if told over the pipe, around the evening fire, to a circle of brother sportsmen." - Pittsburgh Telegraph.

"The book is really very liv ly." - Cincinnati Commercial.

\section{Rollo's Journey to Cambridge.}

Illustrations and illuminated cover by Francis G. ATtwood. T vol. Quarto. 5o cents.

*** A satire upon Life at Harvard College in the form of a parody upon the famous Rollo Story Books. Printed originally in the Harvard Lampoon, and later compiled with the consent of the editors into a sqaure octavo in paper covers. The cleverness of parody and satire and the familiarity of the subject have made this a most decided hit. Already four editions have been exhausted, and the demand promises to continue as long as Harvard Colle;e maintains its infuence on surrounding social life, and humor continues to be an American characteristic.

\section{Bicycle Tour in England and Wales.}

By Capt. Sharpe and A. D. Chandler, President of the Boston Bicycle Club. Illustrated by four large folding maps and seventeen brightly finished albertype engravings. Small quarto. Gilt. 164 pages. \$2.00.

${ }_{*}^{*}$ * The title gives not the slightest idea of the real contents. It is a work of exquisite beauty, displaying rare taste and judgment, laborously and elaborately executed, which none but an intense devotee of the wheel could have carried out to such an interesting degree.

\section{Southern Rambles: Florida.}

By Owes KNox. Very profusely illustrated. 150 pages. Square $12 \mathrm{mo}$. Cloth, \$r.oo; paper, 50 cents.

** An amusing and satirical account of a Winter's Trip to Florida, filled with laughable iıcidents, character studies, descriptions of Southern Life, wholly devoid of exaggeration, showing Florida as it struck the author, and not as the interested guidebook-makers endeavor to prove it to be.

\section{Poetical and Prose Writings of Charles Sprague.}

New edition, with a steel portrait and a biographical sketch, 12mo. Cloth. 207 pages. \$1.50.

\section{New Ingland Interiors.}

By Arthur Littre. A volume of sketches in cld New England places. Thick oblong quarto. \$5.00.

$*_{*}^{*}$ To those far distant, unfamiliar with the nooks and corners of New England, and prone to consider the work of Puritanical colonists noticeable only for its lack of taste, and conspicuous for green blinds and white painted walts, this work will be a revelation."-Boston Daily Advertiser.

\section{The Iand of Gold.}

By George H. Spurr. A novel founded upon fact. Illustrative of proneer nfe in California in "49. 12mo. Cloth. 270 pages. Illustrated. \$I.50. 


\section{The Homes of our Forefathers.}

A selection of the Oldest and most Interesting Buildings Historical Houses, and Noted places in Massachusetts. By Edwin Whitefield. Quarto. Cloth. \$6.00.

** Third improved and enlarged edition of this valuable and interesting work which is composed entirely of plates, in color, accompanied with descriptions.

\section{The Homes of Our Forefathers, 2nd Part.}

Same as above, but embracing the Historical Homes of Rhode Island and Connecticut. By EDWin Whitefield. 4to. Cloth. $\$ 6.00$.

\section{Dr. Howell's Family. Christine's Fortune.}

By Mrs. H. B. Goodwin. New and popular editions in a very attractive style of binding. Each I6mo. Cloth. \$r.0o.

"Of the merits of them, it is difficult to speak too highly. They are written in a style as near perfection as it is possible to conceive. Better books a parent cannot put into the hands of a son or daughter." -Watchman.

\section{Captain Nathan Hale.}

An address delivered at Groton, Connecticut, on the Hale Memorial Day, September 7, I88ז. By EdWard Everetr HALE. Pamphlet. 20 cents.

\section{Peirce's Colonial Lists.}

Civil, Military, and Professional Lists of Plymouth and Rhode Island Colonies, comprising Colonial, County, and Town Officers, Clergymen, Physicians, and Lawyers. With extracts from Colonial Laws defining their duties. 1620-1700. By EBENezer W. Peirce, of Freetown, Mass., member of various Historical and Genealogical Societies. 188r. 8vo. ${ }_{56}^{6}$ pages. Price, $\$ 2.00$.

\section{Henry Krox Thatcher, Rear Admiral U. S. Navy.}

By George Henry Preble, U. S. N. A pamphlet biography of the late Admiral Thatcher. With steel portrait. Price 5o cents.

\section{Tower. Modern American Bridge Building.}

Illustrated. I vol. 8vo. Cloth. \$1.00.

** The only work on modern wooden bridges.

\section{Poems of the Pilgrims.}

Selected by Zilpha H. Spooner. A handsome $12 \mathrm{mo}$. bound in cloth. Bevelled edges. Heavy paper. Gilt edges. Illustrated in photography. The poems, about thirty in number, are selected from Lowell, Holmes, Bryant, Mrs. Sigourney, Mrs. Hemans, and other great writers. Price \$2.00.

\section{James A. Garfield. Tributes from Over the Sea.}

Being selections from Foreign Testimonials to the late President Garfield. Sm. 4to. 50 cents.

\section{The Labor Question.}

The relation of political economy to the labor question. By Carroll D. Wright, Chief of the Mass. Bureau of Statistics of Labor. I vol. Thin I6mo. Cloth. 6o cents.

*** "Col. Wright has discussed the theme in a striking and original manner, and deserves the thanks of the community."-Boston Traveler. 


\section{CUPPLES, UPHAM \& CO.'S}

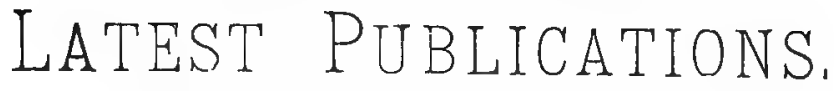

\section{Troublesome Children: Their Ups and Downs.}

By One of Them. With ten full-page colored illustrations, and fifteen plain engravings by Francis G. $\Lambda$ ttwood. I vol. Thick oblong quarto. Exquisitely colored covers. Price, $\$ 2.50$.

** Being wholly without cant, affectation, or any artempt to enter into the subtleties of religious creeds; the purity, sweetness, and combined tenderness and humor, together with its high moral tone, will give it, too, an entrance in to the home of our A merican firesides in a way suggestive of the welcome accorded to the "Fraı,conia" stories and "Alice's Adventures in Wonderland."

\section{Sly Ballades in Harvard China.}

By E. S. M. With many illustrations and in folded paper covers exquisitely designed and colored by Lambert Hollis, after the manner of the famous Paris "Amateur" Series. I vol. Small quarto. $\$ 1,00$.

** The most dainty collection of charming fancies since Praed, and worthy of the school which has produced such inimitable jeu d'esprit as "The Little Tin Gods on Wheels" and "Rollo's 'lour to Cambridge."

\section{Thaddeus Stevens: Commoner.}

By E. B. Callender, member of the Massachusetts Bar. One volume, with portrait, handsomely botind in cloth, $\$$ r.25.

"This life will be welcomed by all who hold the "Old Commoner" in affectionate remembrance." - Watchmean and Reflector.

\section{LONGFELLOW AND EMERSON.}

\section{The Massachusetts Historical Society's Memorial Volume.}

Containing the addresses and eulogies by Dr. G. E. Ellis, Dr. Oliver Wendell Holmes, Charles E. Norton and others, together with Mr. Fmerson's tribute to Thomas Carlyle and his earlier and much-sought-for addresses on Sir Walter Scott and Robert Burns. Illustrated with two full-page portraits in albertype after Mr. Notman's faithful and pleasing photographs of $\mathrm{Mr}$. Longfellow, and Mr. Hawes's celebrated photograph of Mr. Emerson, taken in 1355 , so lighly prized by collectors. One volume. Quarto. Boards. Uncut. Price, \$2.50; or in white vellum, cloth, gilt top, uncut edges, $\$ 3.50$. Limited edition printed.

\section{The Sewall Papers.}

Diary of Samuel Sewall, I674-1729. Edited by Geo. E. Ellis, D.D. 3 vols. Large 8 vo. With elaborate index. $\$ 9.00$ net.

*** A literal transcript, in type, of the famous diary of Chief Justice Sewall, of Massachusets, in possession of the Massachusetts Historical Society. As a minute picture of the manners and customs of early colonial days, abounding in wit, humor, and wisdom in the quaintest of English, it has no prototype. The importance of its publication as a discovery can be compared only with the deciphering of the diary of Samuel Pepys, which it fully equals in interest. 


\section{A Red Letter Day.}

Poems by Lucius Harwood Foote. Handsome cover in entirely original design, the prettiest of the season. Heavy paper. Elegant print. Square I2mo. II2 pages. Cloth. \$1.50.

\section{The Sheep Scab.}

Its nature, prevention, and cure. A handbook for American Shepherds. By HeNry Temple Brown. To which is added by request: "The Classification of Wools and their Marketable Values," an address delivered before the Missouri State Wool Growers' Association at Idaho, Mo., April 5, 1882. I vol. $12 \mathrm{mo}$. Illustrated. Cloth. 5o cents net.

\section{A New Volume of Proverbs.}

Sparks from the Philosopher's Stone. By James Lendall Bosford. I vol. Square I2mo. Cloth. Red edge. Price, \$r.00.

\section{Walking Guide to the Mit. Washington Range.}

By William H. Pickering. With large map. Square $16 \mathrm{mo.}$ Cloth. Price, 75 cents.

\section{What Our Mothers Make.}

A Pamphlet volume of Tried Receipts first issued for the "Little Women's Fair." Very tasty cover. 60 pages. Price, 25 cents.

\section{Cape Cod Folks.}

A novel. By Sally Pratt McLean. With frontispiece by Mitchell, and a charming vignette outline, drawn and engraved by W. J. Dana, showing Cape Cod and the adjacent islands of Nantucket and Martha's Vineyard; the whole tastefully bound in cloth, with unique and elegant cover, designed by $\mathrm{L}$. S. Ipsen, I vol. I2mo. 327 pages. \$I.50. Eleventh edition.

"There is real power in her characterization. Real eloquence in her account of the uncultivated singing. * * * Real pathos in the vague religious opinions, and the intense religious sentiment of these simple brave people." -Boston Advertiser.

"Her description of the provincial traits of this most provincial of all the outlying New England Settlements, are admirable bits of genre workmanship." - Harper's Magazine.

\section{Love Poems and Sonntts.}

By Owen Innsly. Limp, white vellum. I85 pages. \$1.00. Third edition.

"It is a lovely volume of lovely verses on the loveliest of themes."-W. $R$. Alggr.

"It must be confessed, however, that this volume will probably receive nothing but contempt from the admirers of Whitman and Wilde, for with all its strength and passion, it must seem to them basely and despicably pure." $-N . Y$. Evening Post.

"A sense of power still held in reserve fascinates the reader, and throu,h all its changing forms the fervent passion obeys the master's hand."-Literary World.

"The contents are sweet, passionate, and plaintive." $-N$. $Y$. Times.

\section{Driven to Sea; or, The Adventures of Norrie Seton.}

By Mrs. George Cupples. Illustrated. Cloth. Full gilt sides. Large 12mo. \$r.50. Eleventh thousand. 


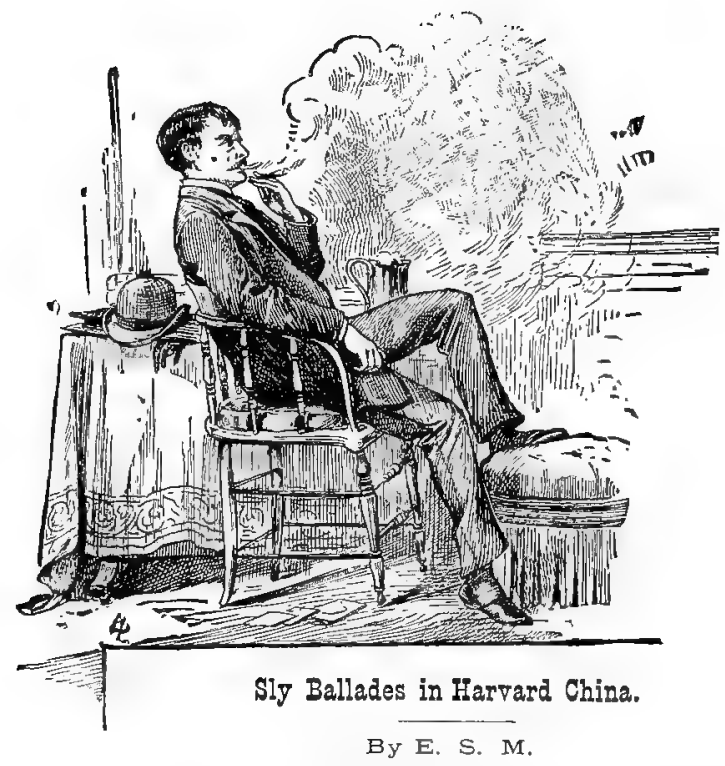

Illustrated with head and tail pieces. In delicately tinted turned-in cover, back and front exquisitely designed by LAMBERT Hollis, à la Paris. "Amateur Series." Orange edges. I vol., square $\mathrm{z} 2 \mathrm{mo}, \$ \mathrm{I}$.

Dainty and unique in style, it will provide bright and amusing Summer reading, appealing to the taste of cultivated people of society. The papers are quite unconventional, and are treated with a rare sense of humor. The versification has the genuine ring. The volume will undoubtedly make a hit. -Boston Saturday Ezening Gazette.

Bright and full of fun. - Boston Globe.

Graceful in fancy, and bright in wit and spirit. The author's drollery is irresistible, and we should think young ladies would enjoy the book as much as the beings of the opposite sex. - Quebec Chronicle.

The author is anonymous - as usual, now-a-days - but he is known as one of the foremost of a band of clever young writers. - Springfield Repubiican.

Writes always like a gentleman. $-N$. Y. Mail.

The volume is of a high order. - Boston Herald.

Suggests Hood at his best. - Boston Fourual.

One of the most charming of Summer books. - St. Louis Globe-Demacrat.

Written in the approved modern Vers de Societie style, with a singular mixture of wit and deep fecling. Many of the verses would not be disowned by Praed, the master-genius of witty verse, or by Calverly, who wrote "Fly Leaves," a few years back. - Boston Advertiser.

Bret Hartecreated quite a sensation in London society by reading these verses in manuscript. $-N, Y$. Pub. Weckly.

The books contain some of the lightest and brightest bits of verse it has lately been our good fortune to read. - The Critic. 


\section{Whence, What, Where?}

A VIEW OF THE ORIGIN, NATURE, AND DESTINY OF MAN.

BY

JAMES R. NICHOLS, M.D., A.M.

I Volume. 12mo. 198 Pages. Cloth, gilt. Mailed, postage paid, on receipt of price, $\$$ r.0o.

CUPPLES, UPHAM \& TO., Peblishers, BOSTON.

\section{'EXTRACTS FROM NOTICES BY THE PRESS.}

From Forney's Philadelphia Press.

"Dr. Nichols' essays will be found stimulating reading. No one can take up the book without feeling the inclination to read further and to ponder on the all-important subjects which they present. Though it is not a religious book in the technical seuse of the word, it is a book which calls for the exercise of the religious nature, and it is a book which in dittusing many sensible ideas will be good."

From Boston Commonwealth.

"The great value of the little book; "Whence, What, Where?" by Dr. James R. Nichols, is in its suggestiveness. It is eminently provocative of thought. Its value is not to be tested by its bulk. It is full of clear thinking, and of accurate statement. Dr. Nichols is severely scientific and, at the same time, devoutly spiritual. Its philosophy is largely that of Swedenborg, without Swedenborg's terrible diffusiveness. We have in it, concisely and clearly stated, all that the strictest scientific research warrants us in believing of man's origin, nature, and spiritual destiny.- Science is shown to be not necessarily opposed to religion and to spirituality."

From Boston Christian Register.

"The book is written in a clear style, and the author's opinions are readily understood. It is refreshing to have such a work from a scientific layman, on topics which too many treat with a supercilious disdain, unbecoming both themselves and the subject."

\section{From Boston Congregationalist.}

"The topics discussed are handled with a good degree of candor, and give in a small space much interesting information and perhaps some profitable epeculation."

From the Lowell Mail.

"Its trutlis may be received as a new revelation from which consolation and happiness may be derived by those who have been troubled with doubts and misgivings." 


\section{By THE AUTHOR OF "THE GREEN HAND"}

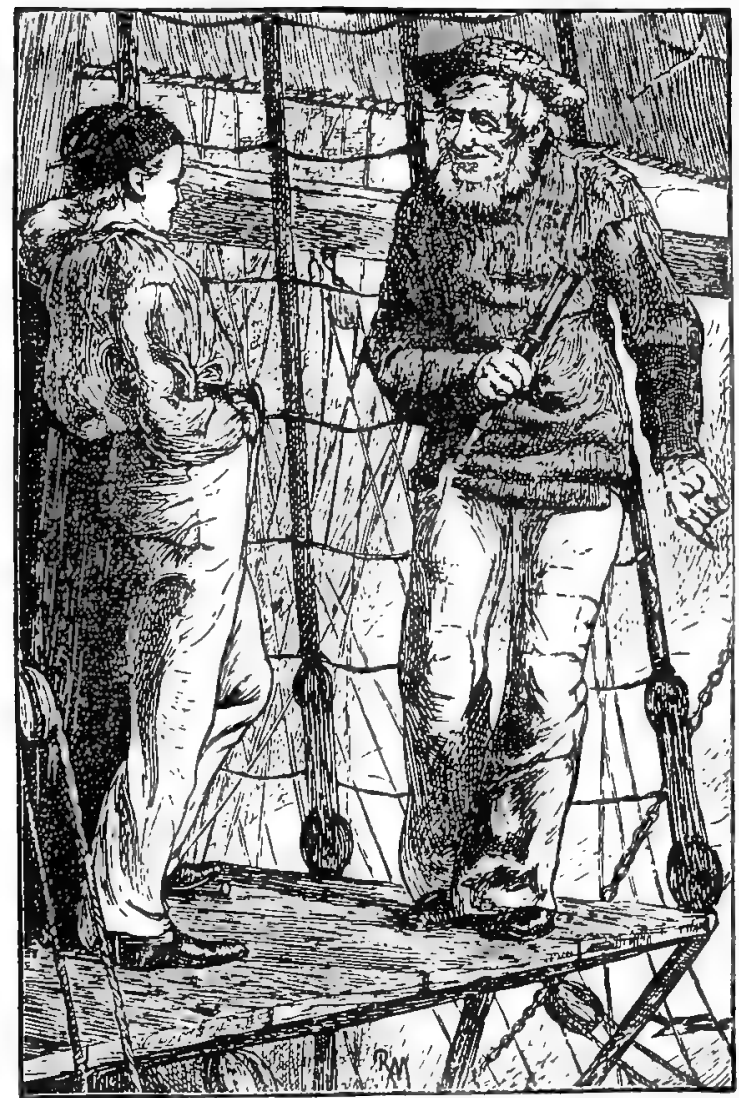

\section{The Deserted Ship.}

A STORY OF THE ATLANTIC.

BY GEORGE CUPPLES

Author of "The Green Hand," "The Sunken Rock," etc. Illustrated. I2mo.

Cloth. Brilliant binding. $\$ x_{00}$. Fourth thousand. New and improved edition.

CUPPLES, UPHAM \& CO.,

Publishers, Boston. 
COPPLES, OPHAM \& CO,'S SUCCESSPUL BOOKS FOR THE YOUNG.

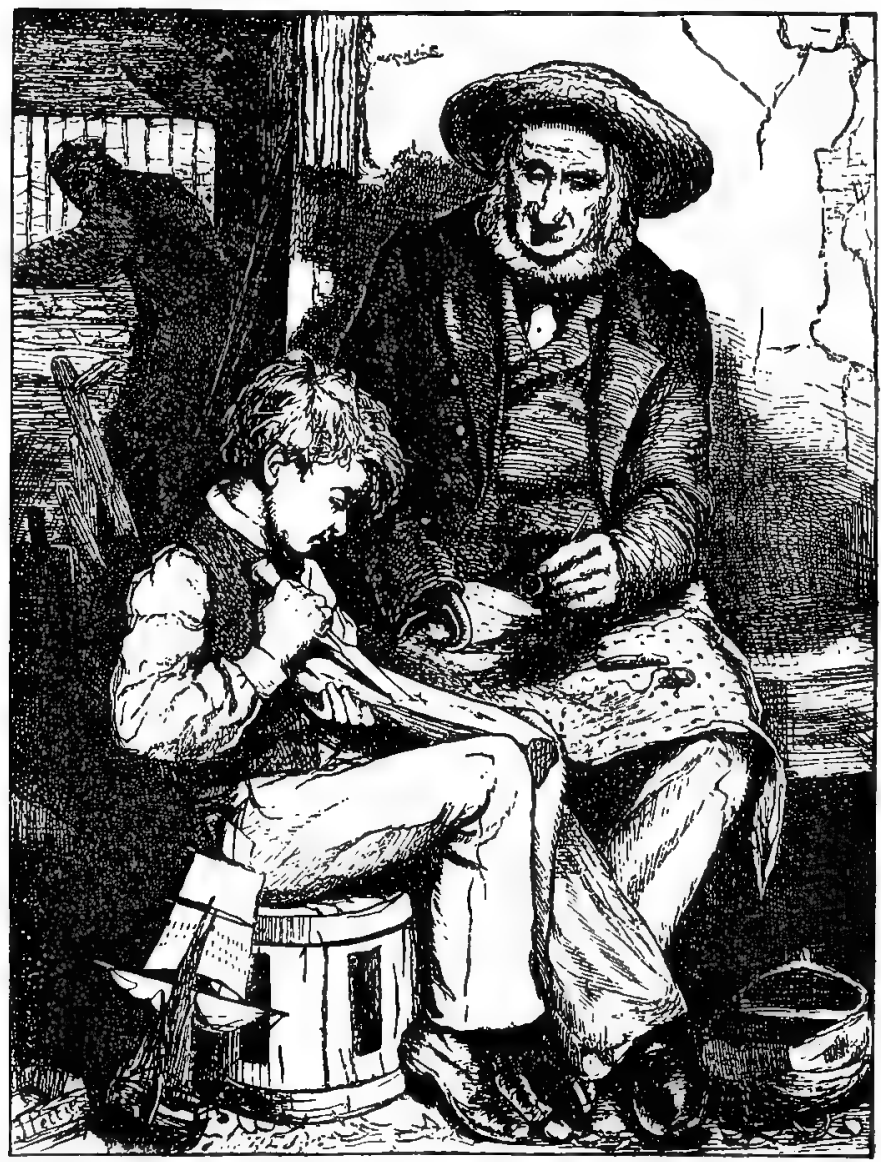

Driven to Sea;

OR, THE ADVENTURES OF NORRIE SETON.

BY MRS. GEORGE CUPPLES.

Illuwtrated. 12mo. \$r.50. Tenth thousand. Mailed on receipt of price, by

CUPPLES, UPHAM \& CO, Publishers, Boston. 





